\title{
The historical morphology of definiteness in Baltic
}

\author{
Florian Sommer \\ Universität Zürich \\ florian.sommer2@uzh.ch
}

\begin{abstract}
The history of the definite adjective in Baltic has been the object of a considerable tradition of research. Most studies approach the problem from an angle which emphasizes the prehistory of the construction and its deeper genealogical ties as well as structurally comparable constructions in neighboring languages.

The present paper, however, is primarily concerned with a thorough morphological description of these constructions in the Baltic languages exclusively, and the trajectory of historical developments within attested diachrony. It will be shown that Lithuanian, Latvian and Old Prussian are best addressed independently as they provide rather diverse challenges to an adequate morphological classification. Special prominence will be given to wordhood issues in Old Lithuanian.
\end{abstract}

\section{Keywords}

Baltic - inflectional morphology - definiteness - adjectives - wordhood

\section{Introduction}

Probably few problems in Baltic linguistics have attracted scholars' attention like the so-called definite adjectives in Baltic and their counterparts in early Slavic. The double set of inflectional paradigms for adjectives in Latvian and Lithuanian, which is associated with a functional opposition resembling the strong-weak distinction of adjectives in Germanic, already caught the eye of early representatives of comparative philology (e.g. Grimm 1848: 963). It is this very resemblance which until today keeps on provoking new-and conflicting-hypotheses concerning possible ties between the two (e.g. Birkhan 1974, Hill 2014). Furthermore, deep-rooted Indo-European origins have been

(C) FLORIAN SOMMER, 2018 | DOI:10.1163/22125892-00601007

This is an open access article distributed under the terms of the prevailing CC-BY-NC license 
suspected for the morphosyntax of these adjectives (Koch 1992, Petit 2009), giving the construction a privileged position within the historical grammar of Balto-Slavic. ${ }^{1}$

Contrary to syntactic and semantic research on the definite adjectives, with their focus on modern synchrony, research on morphology has (with the exception of Stolz 2010, whose analysis is framed in terms of typological markedness and naturalness) traditionally focused on the prehistory of the Baltic forms and their Indo-European connections. The present investigation, however, aims at achieving a thorough descriptive picture of the morphological tendencies at play within attested diachrony and the interdependencies with other types of definiteness marking in Baltic, thus contextualizing this linguistic strategy within the grammar. As the investigation only deliberately deals with the structural aspects of the definite adjective in Baltic and its developments in attested diachrony, the scope is restricted to Latvian, Lithuanian and Old Prussian and excludes congeneric constructions in early Slavic. The prehistoric relations between these two branches of Indo-European and possible further areal or genealogical ties of the definite adjective construction will be addressed in a separate study.

In what follows I will first give an overview of definiteness marking in Baltic (see section 2) and then successively discuss the morphology of definiteness in Lithuanian (section 3.1, with special reference to wordhood issues), Latvian (section 3.2, where the focus will be on paradigm structure), and Old Prussian (section 3.3, which highlights morphosyntactic competition between the adjectives and other elements in this language) before drawing some conclusions (section 4).

\section{Marking definiteness in Baltic}

Definiteness ${ }^{2}$ marking in Baltic is considerably less strongly pronounced than in Germanic or Romance and can be roughly compared to its Slavic neighbors Polish and Russian. There is no obligatory marker of definiteness on noncomplex noun phrases equivalent to the article of e.g. German. It is thus perfectly

1 Naturally, studies stemming from a different background than Indo-European linguistics have shifted the focus to other fields of the grammar, namely syntax and semantics. Such syntactic approaches are represented by works like Valeckienè 1957, Spraunienè 2008 and Holvoet and Spraunienè 2012.

2 For an understanding of the term 'definiteness', and the application of current frameworks to a Baltic language (Lithuanian), see Spraunienè 2008. 
reasonable to speak of the Baltic languages as not belonging to the category of article languages, ${ }^{3}$ relying on the absence of a dedicated, obligatory and deeply entrenched morphosyntactic marker of definiteness. However, the situation is of course more complex. On the one hand, definiteness in these languages is not simply a matter of pragmatic inference, but something that can be signaled by linguistic means. On the other hand, there are two morphosyntactic patterns that can be considered dedicated markers of definiteness, one of them highly reminiscent of the prototypical article, except for its lack of obligatoriness. The other is a special form of the adjective, which is the subject of the present paper. This form is present as a category in all three attested Baltic languages, including the extinct Old Prussian, but differs in its morphological design and its actual usage across these languages. While the discussion of definiteness in Baltic has centered around the adjectives, it is important to stress that the Baltic languages employ several strategies for indicating the referential status of a given noun phrase (NP), belonging to different parts of the grammar.

One strategy to induce a definite reading of a given NP is word order, where for example in simple intransitive sentences placement before the verb, as a rule of thumb, tends to be associated with definite NPs, while placement after the verb often corresponds to an indefinite reading of the referent. Compare the following examples from present-day Lithuanian:
a. žmogus
atëjo
man.NOM.SG come.PST.3
'(the) man came'

b. atëjo žmogus

come.PST.3 man.NOM.SG

'(a) man came'

However, word order is extremely sensitive to all sorts of contextual factors like e.g. discourse prominence, and neither (1a) nor ( $1 \mathrm{~b}$ ) enforces a single reading with respect to definiteness, which means that word order is an optional and additional cue rather than an explicit strategy.

A second possibility is differential argument marking. Here the genitive case can be employed to explicitly rule out definite readings in certain grammatical

3 The terms 'article' and 'article language' are, of course, to be understood as cover terms in a nontechnical sense, since there is no consensus about what exactly is to be considered an article. I will also adopt the notion of D-element from Himmelmann 1997 below. In the examples, such elements are nonetheless glossed as 'DEM' in accordance with common usage. 
environments, namely mass noun and plural count noun subjects and objects as in example (2). The degree to which this use of the genitive is employed differs considerably in Latvian and Lithuanian (Old Prussian data is very sparse, but see Endzelin 1944: 137 for the partitive genitive). In the present-day variety of the former it is virtually absent.

\section{(2) svečiu ateina \\ guest.GEN.PL come.PRS.3 \\ 'guests are coming' / *the guests are coming'}

It is evident that this type is clearly restricted in scale and it is banned from several contexts. Naturally, structural constraints preclude the genitive from appearing in prepositional phrases where the preposition governs a case other than the genitive. In negative contexts and in object contexts where the genitive is required by the governing verb, such distinctions are neutralized, ${ }^{4}$ as in all other cases where the genitive fulfills a grammatical function (like adnominal modifying in noun phrases etc.). ${ }^{5}$ But besides such contexts, where the grammar prohibits or neutralizes such marking, there are cases which render it obvious that the genitive is not a means of primarily marking definiteness but rather something that falls out naturally from the general semantics associated with this strategy. The reason is that count nouns in the singular do not allow for genitive case marking to the end of ensuring an indefinite reading. Saying *atëjo žmogaus (where žmogaus is genitive singular) to exclude a definite reading in $(\mathrm{lb})$ is impossible, although prima facie no structural constraints apply. This points to constraints rooted in semantics. Were the genitive simply a case that marked indefiniteness, these limitations would have to be considered purely idiosyncratic and unmotivated. However, they are the natural result of a-broadly speaking - partitive function, as singular count nouns in these contexts do not allow for a partitive reading. ${ }^{6}$

Contrary to word order and case-marking, the use of an atonic demonstrative pronoun as a definiteness marker can be considered to represent a truly dedicated strategy in terms of referential semantics. In fact, this usage is so close to the function performed by the article in other languages that

4 For the complicated situation with the marking of subjects in negated intransitive clause see, however, Semėnienè 2005 .

5 Standard Lithuanian, and most other varieties of the language, mark negated direct objects by the genitive case. Lithuanian, broadly speaking, patterns with Polish as to argument marking in the the genitive, see Falkenhahn 1963.

6 See Seržant 2014 for the syntax and semantics of the partitive genitive in Lithuanian. 
for Lithuanian already Rosinas in the 1970s stated: "That Lithuanian too has an article, it seems, no one doubts today." That the construction in question still differs considerably from the traditional article has led the same author to coin the term "arthroid" (artroidas), which is still used in Baltic linguistics (cf. e.g. Sprauniene 2008). The crucial difference is that the Baltic languages do not use these elements consistently, and dropping them in a given sentence does not render the utterance ungrammatical and is often a matter of style. ${ }^{8}$ The only obligatory context cited in the literature is certain expressive statements with derogative terms, where the D-element is required (Rosinas 1972: 86, see also Spraunienè 2008). But this obligatoriness is best understood not as being grammatical in nature but rather as attributed partly to the lexicon. The most common context for this marker to appear is anaphoric reference within utterances. Already in the most ancient stages of the language (i.e. the 16th century) there are, however, other suitable contexts as well, compare example (3):

(3) Ir melde ghi tas wiras ifch and beseech.PST.3 3.ACC.SG DEM.NOM.SG man.NOM.SG from kuria welinai ifcheija, idant butu fu REL.GEN.SG devil.NOM.PL depart.PST.3 that be.SUBJ.3 with io.

\section{INST.SG}

'Now the man out of whom the devils were departed besought him that he might be with him.' (BrB, Lk 8.38)

In (3) the definiteness marker appears within a noun phrase including a relative clause, which by virtue of being restrictive in nature provides additional information about the head, allowing the addressee to easily identify the referent and thus favoring the use of a D-element. ${ }^{9}$

While it is difficult to track the development of this type of definiteness marking over time, the overall picture seems to point towards a rather

7 “Kad lietuvių kalba irgi turi artikeli, šiandien, rodos, niekas neabejoja." (Rosinas 1972: 83)

8 This holds true for at least Latvian and Lithuanian; the difficult case of Old Prussian (see also Parenti 1995) is discussed below.

9 Note, however, that the use of the definiteness marker in example (3) is the result of two intertwining factors promoting definiteness: beside the relative clause, the context is also anaphoric, since the man has been introduced already at the beginning of the passage. But (3) is the first and only case where a definiteness marker is used in this episode. Note also that the main source for Bretkes translation of Luke was a Latin text. 
stable but low-profile entrenchment in several contexts without any considerable spread to new domains. For the study of the historical development of definiteness marking it is important to note that in Lithuanian this equilibrium has lasted already for almost 500 years. In Latvian the situation is similar but complicated by the fact that almost all early texts were composed by German native speakers who used the D-element rather excessively.

There is, however, a strategy of marking definiteness on noun phrases in the Baltic languages which is both restricted in scope, since it can only be employed with complex noun phrases containing an adjective, and highly peculiar with respect to its morphosyntactic properties, most notably the locus of its realization on the adjective. This construction will now be discussed in detail on the basis of the linguistic facts of the three attested Baltic languages.

All Baltic languages which are attested in more than fragmentary language documents and names (i.e. Latvian, Lithuanian, and the extinct Old Prussian) exhibit a twofold inflection of adjectives, one of them being utilized mainly in definite contexts. While there is thus a common background, the morphological structures of the inflectional paradigms differ considerably and presuppose independent and diverging developments.

\subsection{Lithuanian}

3.1.1 The modern language

Standard Lithuanian has two clearly defined inflectional sets for adjectives without any interrelational syncretisms. The first shows basically the regular inflectional endings of the nominal system with some hybridization from the pronominal declension. One of the cells has, however, an ending unique to adjectives: The nominative plural in $-i$ of masculine $a$-stem adjectives is found neither in the inflectional paradigms of the substantives nor with the pronouns, which sets off the adjectival paradigm from all other paradigms. In synchronic terms, adjectival $-i$ has to be taken as a marker of its own, as the form cannot be explained with recourse to the phonological system of the language as a mere variant of pronominal -ie to which it is historically related.

The second inflectional set, however, is quite specific. It is obvious at first glance that here, structurally speaking, an additional element attaches to the inflected word form at its right edge, resulting in transparent additive word 
TABLE 1 The inflection of mãžas 'little'

Case

Masculine

Singular
Plural

Simple Definite Simple Definite

\begin{tabular}{|c|c|c|c|c|c|c|c|c|}
\hline & Simple & Definite & Simple & Definite & Simple & Definite & Simple & Definite \\
\hline Nom. & mãžas & mažàsis & $m a \check{z} i$ & mažíeji & $m a \check{a ̆ a ̀ ~}$ & mažóji & mãžos & mãžosios \\
\hline Gen. & $m \tilde{a} z ̌ o$ & mãžojo & mažũ & mažũ $\tilde{j}$ & mažõs & mažõsios & 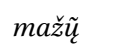 & mažũju \\
\hline Dat. & mažám & mažájam & mažíems & mažíesiems & $m \tilde{a} z ̌ a i$ & mãžajai & mažóms & mažósioms \\
\hline Acc. & 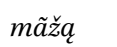 & $m \tilde{a} z ̌ a j i$ & mažùs & mažúosius & $m \tilde{a} z ̌ a$ & mãžają & $m a \check{a} a ̀ s$ & mažąsias \\
\hline Inst. & mažù & mažúoju & mažaĩs & mažaĩsiais & mažà & mažája & mažomis & mažõosiomis \\
\hline Loc. & mažamè & mažãjame & mažuosè & mažuõsiuose & mažojè & mažõjoje & mažosè & mažõsiose \\
\hline
\end{tabular}

Feminine

Plural

forms in the majority of cells of the paradigm. The inflection of both sets is illustrated for the inflectional classes in - $a$ and - $a$ in table $1^{10}$

This element is highly reminiscent of the personal pronoun of the third person $j i s, j i$ (cf. table 2). Bearing in mind that these forms mark definiteness on noun phrases, it is, however, reasonable to call this item a definiteness marker and not a pronoun. ${ }^{11}$ The definiteness marker too inflects for the same categories as all other nominal or pronominal forms, i.e. case, number and gender. Note again that the shape of this element differs in several cells from that of the personal pronoun (e.g. nom.pl.masc. jiẽ with pronouns versus -ji with adjectives). While this double inflectional design is remarkable in itself, the exact morphological behavior of this item is even more interesting, as the individual cells can in fact exhibit forms that deviate from the principle of concatenation and transparency.

If one assumes the underlying form of the definiteness marker to be $-j$ - (plus inflectional ending), then the statement that the item is clearly discernible as a distinct item in most of the cells of the paradigm requires some slight readjust-

10 For complete paradigms - including the forms for the dual—of all inflectional classes see i.a. Senn 1966, especially pp. $164-168$ for the definite forms. A detailed presentation of the attested material is Zinkevičius 1957.

11 That this is the only truly dedicated formal marking in the (standard) language is stressed by Spraunienė 2008: 115: "Vienintelè morfema, kurią galima būtų sieti su formaliu apibrèžtumo žymėjimu lietuvių kalboje, yra įvardžiuotinių būdvardžio formų įvardinè morfema." (The only morpheme one could possibly connect with the formal marking of definiteness in Lithuanian is the pronominal morpheme of the pronominalized [i.e. definite] adjective.) See above on article-like structures in less formal registers. 
TABLE 2 The inflection of Lithuanian 3rd person pronouns

Case Masculine Feminine

\section{Singular Plural Singular Plural}

\begin{tabular}{|c|c|c|c|c|}
\hline Nom. & jis & $j i \tilde{e}$ & $j i$ & jõs \\
\hline Gen. & jõ & $j \tilde{u}$ & jõs & $j \tilde{u}$ \\
\hline Dat. & jám & jíems & jái & jóms \\
\hline Acc. & $j \tilde{z}$ & juõs & $j \tilde{q}$ & jàs \\
\hline Inst. & juõ & jaĩs & jà & jomis \\
\hline Loc. & jamè & juosè & jojè & josè \\
\hline
\end{tabular}

ment. In reality, this is only the case where the definiteness marker attaches to a vocalic ending of the adjective. In all other cases the glide fuses with the preceding consonant which, as a result, is palatalized. Between consonants and front vowels it is simply lost. It is therefore difficult to maintain an analysis where the definiteness marker is a clearly discernible morpheme with distinct boundaries (as is done e.g. in Stolz 2007). Both processes are, however, diachronically regular and synchronically valid rules of the phonology of Lithuanian within the domain of lexical words but not between them, i.e. as external sandhi. As these processes are a regular part of the phonological system, the morphology of the affected forms nonetheless cannot be said to be intransparent or idiosyncratic.

There are, however, cases where deviation cannot be reduced to phonology. From a phonological point of view, these deviations can be roughly classified into two types: loss of material and gain thereof.

Several forms exhibit the loss of $m$ in adjectival case endings. Compare the following pairs: Dat.sg.masc. mažám : mažájam, loc.sg.masc. mažamè : mažãjame, dat.pl.masc. mažíems : mažíesiems, dat.pl.fem. mažóms : mažósioms, inst.pl.fem. mažomis : mažõsiomis. This loss is clearly not phonological in nature, nor can it be attributed to a historical sound change for that matter, $m$ being notably one of the most stable sounds in Lithuanian. While this loss is usually understood as a phonological irregularity, i.e. dissimilation (thus e.g. Stang 1966: 271), there is good reason to attribute this aberration to morphology (see the analysis below). Old Lithuanian still has some forms with fully retained endings in both positions, e.g. dat.pl. geriemsiems (masc.) and geromsoms (fem., the palatalisation is not marked in the orthography) in the 
grammar of Daniel Klein, loc.sg.masc. dangiszkameieme $(\mathrm{MgT} 3520)^{12}$ and inst.pl.fem. tikromisiomis (DaP 249). ${ }^{13}$

Vowels, too, are subject to deletion in some cases. Where $e$ and $i$ appear in word-final syllables in the inflectional endings of simple adjectives, they do not appear in the definite forms: loc.sg.masc. mažamè : mažãjame, loc.pl.masc. mažuosè:mažuõsiuose, loc.sg.fem. mažojè :mažõjoje, loc.pl.fem. mažosè: mažõsiose have $e$-less adjectival inflectional endings, mažomis : mažõsiomis shows the absence of $i$ in the adjectival ending (beside the loss of $m$ ). Contrary to the other instances of loss of phonological material, these processes are also perfectly legitimate in simple adjectives, i.e. for the locative singular of the masculine the simple adjective can be mažamè or mažañ, the instrumental plural of the feminine has mažomis and mažoñs side by side. While the loss of these vowels in absolute word-final position is widely attested across all word classes, the process cannot be understood as being purely phonological in nature. With the exception of the vocative singular of the o-stems, endings which consist of the vowels [i] or [e] only are immune to such reduction. This exemption makes the process morphophonological, as the notion of ending in Lithuanian cannot be interpreted in phonological terms.

The fact that vowel deletion is essentially morphophonological has implications for further analysis and especially its diachronic dimension as well. In Old Lithuanian forms like šventuosejuose ( $\mathrm{DaP} 238_{10}$ ) still existed, where the final $[\mathrm{e}]$ of the adjectival inflectional ending is preserved. Theoretically, one could argue that at that stage the adjectives and their definiteness markers still consisted of two discrete phonological domains with the inflectional ending of the adjective at the right edge of the first, hence phonological loss of the vowel could apply. But since this loss is morphophonological in nature, no such conclusions can be drawn. It is not even possible to tell wether this loss is in fact restricted to the right edge of the phonological domain in questions. Another, and equally probable, interpretation would be that the loss applies to the inflectional morphs as such, and that the apparent loss in word-final position is simply epiphenomenal. For present-day Lithuanian, such an analysis, however, cannot be maintained, at least with respect to the definite adjectives, since there are no variants with [i] and [e] preserved in the adjectival endings.

A purely local, but rather opaque problem is the loss of the diphthong in the dative singular of the feminine (mãžai : mãžajai). It is difficult to decide whether this form is the result of regular sound change or another instance

12 I adopt the sigla of Old Lithuanian texts given in Hock 2015.

13 I leave aside forms where the Old Lithuanian ending as such differs from the modern standard, e.g. dat.sg.masc. ghrieschnamuiem ( $\left.\mathrm{ViC}_{71_{9}}\right)$. 
of morphophonologically conditioned simplification. The absence of a string [aij] in the language can, however, be interpreted as mild support for the first explanation. ${ }^{14}$

A second type of deviation is the appearance of long vowels in the adjectival endings of the definite forms, where the simple adjectives have short vowels in their endings: inst.sg.masc. mažù : mažúoju, nom.pl.masc. maži : mažíeji, acc.pl.masc. mažùs : mažúosius, nom.sg.fem. mažà : mažóji, acc.pl.fem. mažàs : mažásias. These synchronically obscure correspondences are deeply rooted in the prehistory of Lithuanian and are the result of a well-known sound law established by Leskien in 1881, which now bears his name (cf. Leskien 1881): long vowels, including diphthongs, are shortened in word-final position if they have acute intonation. While this does not necessarily account for the short form of the definiteness marker (see Hock 2016 and the discussion below), what it does account for is the allomorphy of the adjectival inflectional endings: being protected by the additional syllable of the definiteness marker, they are no longer in word-final position and therefore do not undergo reduction. Diachronically speaking, the process is not one of gain of phonological material in the definite adjectives, but rather one of loss in the simple forms. ${ }^{15}$ While the relevant forms are completely regular with respect to their diachronic development, they have to be considered idiosyncratic aberrations within synchrony, which diminish the transparent design of the underlying word formation process.

The principle of concatenative addition is also violated in the definite nom.sg.masc. mažàsis contrasting with simple mãžas. The latter accents the root, while the former has stress on the inflectional ending of the adjective. Again, on a synchronic level, this cannot be explained by invoking general rules of accent placement, but has to be projected back into the prehistory of Lithuanian accent and intonation. It is usually assumed that mažàsis preserves the original accentuation of the inflectional ending of the adjective and that mãžas is the product of a process dubbed "Nieminen's Law" by which the accent was retracted from short $a$ in word-final syllables. As in the case of Leskien's Law,

14 See below for a similar, but more complicated, problem in Latvian.

15 Here I will just mention as an aside that Leskien's Law is crucial for dating the rise of the definite adjectives in the relative chronology of Lithuanian as it is one of the few reliable reference points in time. The law serves as a clear terminus ante quem for the acquisition of single word status by the definite adjectives. However, it is probably comparatively recent even within Lithuanian (as per Stang 1966: 116) and therefore does not help with respect to whether the definite adjectives were there as such already in Proto-Baltic (as argued by Kazlauskas 1972) or whether they are the result of developments that took place in Proto-Lithuanian, Proto-Latvian and Proto-Old-Prussian respectively (for a defence of this scenario see Zinkevičius 1978). 
the acquisition of single-word status must therefore predate this sound change, as otherwise the form would have to be †mãžasis. ${ }^{16}$ Again, while this shift of accent can be explained on historical grounds, there are no phonological rules by which one could derive one word from the other within synchrony.

In conclusion, the picture of the morphology of the definite adjective is far from being homogeneous and unified. The historically underlying principle of concatenation is still visible in some cells of the paradigm (e.g. acc.sg.masc. $m \tilde{a} \check{z} q$ : $m \tilde{a} \tilde{z} a j i \bar{l})$, but obliterated in others. This blurring is the result of various processes and is of a gradual nature. A form like mažàsis, where only the placement of the accent is deviant with respect to the simple form, is arguably more easily analyzable than is mažõsiomis when compared to mažomis. Leaving aside the synchronic phonological rule of the loss of the initial glide of the definiteness marker, two reasons for the emergence of aberrant forms can be distinguished. One is the impact of historical sound laws, which led to the preservation of ancient inflectional endings of the adjective, thereby triggering something that can be described in terms of allomorphy. The second is morphological change without influence of phonological processes. Contrary to the phonological changes, which incidentally effect conservation of morphology, the morphological changes lead to the loss of inflectional material. However, it seems that it cannot be excluded that phonological features nonetheless played a (subordinate) role in the loss. Conspicuously, the loss of [m] targets forms whose precursors exhibited structures with closed syllables in the adjectival endings, e.g. dat.pl. mažíesiems ( $\leftarrow$ mažíemsiems) and mažósioms $(\leftarrow$ mažómsioms). But even if one formulated such phonological properties as a restrictive domain for the operation of the loss, they would be unable to account for forms like mažã jame where one would expect * mažãmiame. The natural conclusion is therefore that the loss is internal to morphology and independent of regularities in other areas of the grammar.

Such behaviour is in line with the observations on 'trapped morphology' by Harris and Faarlund 2006. The attachment of additional material (often formerly enclitic) after inflectional endings frequently leads to reduction of the latter on purely morphological grounds, irrespective of phonology. In the paradigm of the definite adjectives in Lithuanian, the very same attachement of additional material has, however, also functioned as a conserving factor for the

16 For references on Nieminen's Law the reader is referred to Olander 2009: 105 whose own views on the subject nevertheless differ. As the retraction, on the one hand, touches upon ardently disputed essentials of Balto-Slavic accentology and, on the other hand, does not yield additional results for an analysis of the definite adjectives, I refrain from discussing it further. 
formerly word-final endings of the adjective, which can analogically be considered 'sheltered morphology' from this perspective. But both processes yielded the same results in that they removed the morphophonological makeup of the definite adjective from the ideal of concatenative addition.

\subsubsection{Old Lithuanian}

Old Lithuanian differs remarkably from the modern standard language with respect to several aspects of the definite form of the adjective and thus requires a separate treatment, even though most of what has been said above also holds true for this variety of the language. But as an important qualifier, one has to state from the outset that Old Lithuanian is by no means a monolithic normalized language, but split up into several subgroups of idiolects with cross-cutting boundaries of religious and regional affiliations. ${ }^{17}$ In addition, the corpus of Old Lithuanian is unbalanced to a significant degree because of the uneven size of the individual texts. This complicated situation is also reflected in the way Old Lithuanian authors employ the definite and simple forms of the adjectives. Definite forms are comparatively rare in Sirvydas (Specht 1929:32), while an author like Willent, on the other hand, uses them quite consistently (see Ford 1969: 116 for examples).

The importance of the older stages of the Lithuanian language for the study of the origin and the development of the definite adjective is basically twofold. Both aspects are essentially morphosyntactic in nature and relate to the status of the marker -ji-. The first of these is the striking and oft-cited feature of the definite adjective: that the placement of the definiteness marker in compounded adjectives, especially participles, varies and the marker can be placed after the 'preverbal' first member of the word form as in (4). While it has to be stressed that this is a exceedingly rare phenomenon-Hock (2016:376) counts a total of 23 examples - it is nonetheless of great significance for an historical understanding of the definite adjective's morphological development. ${ }^{18}$

17 In fact, the best way to classify the language of single texts and their relation to what we understand to be Old Lithuanian (ISo 639-3: olt) is to apply an extended version of the notion "doculect" as developed and advocated by Cysouw and Good (2013) for crosslinguistic studies. But since mainly (extreme) low-frequency phenomena will be discussed in this article, a further segmentation is not feasible and I will therefore deliberately avoid it.

18 The case of the definite adjective thus diverges from that of the reflexive marker, which has kept mobility of position until today and is widely attested. Since the two constructions also differ with respect to other parameters (e.g. the reflexive marker lacks inflectional potential), the comparison of the two types will not be pursued here any further. 
(4) Kurie efte ápfunkinti,

REL.NOM.PL be.PRS.2PL weighted.down.NOM.PL

Nu-ghie-wargie ifztrofzkinti, Manimp

ex-DEF.NOM.PL-hausted.NOM.PL thirsty.NOM.PL 1SG.ADESS

ataufzinfites.

recover.FUT.2PL

'You, who are weighted down, the exhausted and thirsty, with me you will revive.' ( $\left.\mathrm{KnN}_{2}^{1}{ }_{2} 18719-20\right)$

As can be seen from (4), ${ }^{19}$-ji- does not show up in word-final position but after the first element of the compounded form. What is important is that it retains its inflectional potential and shows the required case form, which corresponds to the one at the end of the adjective, in this case, the nominative plural. The definite marker appears in its full form matching the independent pronoun (jie 'they') and not the reduced form - ji. The latter is the usual shape of this element in final position, except for active participles, where it varies with -jie. Due to the sparseness of data, it is not possible to fully ascertain the exact relation between the two forms in exactly the present morphological (and subsequently phonological) context, since it seems that in the Knyga Nobažnystès there are no unprefixed definite past participles in the nominative plural, which would have placed the definiteness marker at the right edge of the word form. However, past passive participles in -ta-, the inflectional morphology of which patterns with other adjectives of the $a$-class, clearly demonstrate that the shape of the definiteness marker depends on its position in the word: at the right edge it is -ji (e.g. $\mathrm{KnN}_{1}^{1}{ }_{2}{ }_{21}$ piktie-ghi evil.NOM.PL-DEF.NOM.PL), internally it is -jie(e.g. $\mathrm{KnN}_{1}^{1}{ }_{1} 7_{21}$ su-ie-spausti PV-NOM.PL-DEF.NOM.PL-pressed.NOM.PL). Thus the constellation between the word-final and the internal marker is not just simply one of movement but more complex.

Before evaluating the exact relations between word-internal -jie- and -ji in word-final position, we must briefly address the (pre-)history of the latter and its equivalent -jie in Old Lithuanian participles and $u$-stem adjectives. A recently proposed solution by Hock (2016), expanding on an observation by Stang (1966: 273), explains the distribution of the two forms as a dissimilation in the the adjectival endings of the $a$-stem adjectives: ${ }^{*}$-jie-jíe $>{ }^{*}$-jíe-ji. While Hock is not explicit about how he envisages the exact nature of this process, there is evidence that it did not take place due to some general restrictions in

19 As in all examples, I have resolved the arrangement of metrical texts into lines and replaced virgules with commas. 
the phonology of the language disallowing a string [iejie]. Unfortunately, there are no other cases where the prerequisites for the identical sequence to appear would be given. However, in the very same paradigm we find an instance of an array of two diphthongoids [ie]: the dative plural of the definite adjectives ends in -iesiems. ${ }^{20}$ In addition, Lithuanian generally does not exhibit such phonological restrictions and so a synchronic rule enforcing dissimilation of identical vowels with respect to the feature [ \pm length] in the domain of adjacent syllables would be singular in the language. Keeping in mind the general sporadic nature of dissimilation, a purely phonological process cannot be excluded with absolute certainty, but the overall picture definitely disfavors such an interpretation. On the contrary, it suggests an analysis in terms of morphophonemics, that is the attested forms are the phonological output of a diachronic development which is morphological in nature. This view would be in keeping with what can be seen in other cells of the paradigms. The operations at work offer a varied picture and seem to defy a unified explanation (e.g. haplology, denasalization, vowel loss), ${ }^{21}$ but all of them, including the alleged dissimilation in the nominative (and accusative) plural of the masculine, can be subsumed under the heading of reduction, which leads to an increased degree of intransparency with regard to the morphological segmentation.

Although such a unified approach should be preferred over one assuming several independent and unrelated irregular phonological developments within one and the same paradigm, the question that arises is if it can account for the differing ending -jie in the participles and $u$-stems. As in the purephonology approach to the problem, the class of the $a$-stem adjectives possesses a quality which sets it off against these participles and $u$-stems. The nominative plural of the masculine of the latter is identical in both the definite and the indefinite forms, e.g. there is no allomorphy. This is not the case with the $a$-stems, however:

\section{Class Nom.pl.indef Nom.pl.def}

\begin{tabular}{lll}
\hline participles & $-a,-i,-e$ & $-a,-i,-e+j i e$ \\
$u$-stems & $-\bar{u} s$ & $-\bar{u} s+j i e$ \\
$a$-stems & $-i$ & $-i e+j i$ \\
\hline
\end{tabular}

\footnotetext{
20 Other examples include dieviene 'goddess' and viešieji, the nominative plural masculine of the definite form of viešas 'public'.

21 Whether or not some of these processes are due to some horror aequi, rooted at a very
} 
As the table shows, on the one hand, the participles have an ending -VN (where vN represents an originally nasalized vowel, the coloring of which depends on the stem class of the corresponding verb). and the adjectival $u$ stems have $-\bar{u} s$ in both paradigms, which is enlarged by -jie in the definite paradigm. On the other hand, the $a$-adjectives have $-i$ in indefinite forms and $-i e-(j i e)$ in the definite forms. The latter shape of the nominative plural marker of the masculine is idiosyncratic as it cannot be related to the ending $-i$ of the simple adjectives by synchronic phonological rules. ${ }^{22}$ The original word ending *-iejie thus differed from - $\bar{u}$ sjie and -VNjie, which in their first part kept the form of the corresponding simple form by being completely detached from their simple counterparts and thus showing already a considerable degree of fusion between the two elements. This fact created the preconditions for the further development, which now lends itself to integration into the general picture exhibited by the definite adjectives. As already mentioned above, the paradigm generally trended toward reduction of linguistic material in the cells. The difference between the nominative and accusative plural of the masculine and the other forms is that in these cases the reduction targets the final (i.e. formerly pronominal) element and not the first (i.e. the formerly inflectional ending of the adjective). But there is good reason for this difference. As a comparison between the endings of the simple adjectives of the $a$-stems, or more precisely the i $a$-stems like didelis 'large' in the masculine and io-stems like graži 'beautiful' in the feminine reveals, the absolute endings of the two paradigms are exactly the same. Assuming a general trend toward reduction of complexity of the original forms, the need to align the definite adjectives with the general adjective inflection must have acted as a constraint on this reduction. This is exactly why the nominative and the accusative had to reduce the second and not the first of the composite parts, since otherwise they would have been left with absolute endings foreign to the adjectival paradigm. The forms where we notice no reduction are those where it would have led to syncretism with those of the indefinite paradigm.

Beside the reduction peculiar to such composite forms, another driving force behind the development of the forms of the definite adjectives, which in the end took on the shape of a constraint on this reduction, was the alignment

deep level of the cognitive apparatus, is a moot point to argue, since it is obvious that repetition was perfectly tolerable in other cells of the paradigm.

22 Pace Stolz (2007: 227), who states that "the definiteness marker is clearly a bound allomorph of the personal pronoun of the zrd persons", the shape of which is supposed to be determined by a rule of Lithuanian phonotactics. But there is no such rule. 
of the inflectional profile of the definite adjectives with those of the other adjectival forms while still keeping the two paradigms distinct. As with the dissimilation account, in the scenario presented here there arises no need to explain the absence of Leskien's Law in the unshortened forms if one assumes, with Hock 2016, that the forms with $i e$ - and $u o$-vocalism underwent metatony already before forming a phonological domain with their host, to which the law would have then applied. The question naturally arises how this relates to the full forms of the definiteness marker in the nominative plural of the paradigm of the $u$-stems and participles. The answer is provided by the fate of these forms within the diachrony of the language itself (again see e.g. Hock 2016). Originally the shortened form came into existence in the paradigm of the $a$-stems, as explained previously. In the first step, the shortened $-j i$ spread to other paradigms, a process that can be observed already in the Old Lithuanian texts, and in the second step, the io-stem endings ousted the inherited endings in the corresponding cells of the other paradigms completely. Since there are only a few $u$-stems with the full form -jie, but many participles, the assumption that the latter were a stronghold of resistance against the encroachment of $-j i$ from the $a$-stems is justified. This hypothesis can be backed up by other considerations as well. As exemplified by (4), the marker of definiteness was not tied to the usual final position in compounded participles, which suggests that they had not reached the same degree of fusion as in the other adjectives.

But we also find complex adjectives where the definiteness marker nonetheless appears not after the first element, but at the end of the whole form: pa-skirtumé-iime urede 'in the assigned office' ( $\left.\mathrm{DaP}{ }_{20}{ }_{18}\right)$, Pri-gimtame-ieme grieke 'in original sin' (MT $55 \mathrm{a}_{8}$ ), with negation ne pirmamé-iime kune 'not in the first body' ( $\left.\mathrm{DaP} 195_{21}\right)$. These cases might provide hints of restrictions in the phonology which acted on the forms with the internal definiteness markers. On the grammatical side these forms are all locative singulars of the masculine, but on the phonological side they also share a feature, namely the disyllabicity of the definiteness marker. And indeed there are no disyllabic morphs among the forms with internalized definiteness markers (Hock 2016: 376). Especially telling are the following examples:

\section{(5) id wel giaray darića}

that again well do.SUBJ.1SG

Nu-iam-puluosia-muy

PV-DEF.DAT.SG-fall.PART.PRET.ACT-DAT.SG

'that I again might help the fallen (one)' $\left(\mathrm{KnN}_{2}{ }_{2} 241_{15}\right)$ 


\section{(6) Pharizeuszai Nedeloie}

Pharisee.NOM.PL week.LOC.SG

pra-ie-szokus-ioie suprast arba ne

PV-DEF.LOC.SG-jump.PART.PRET-LOC.SG understand.INF or NEG

noreio, arba ne galeio

want.PRET.3 or NEG can.PRET.3

'The Pharisees in the past week either did not want to, or could not understand.' (DaP $346_{37}$ )

As example (5) shows, the form of the inflection of the definiteness marker is different from the adjectival ending and not just a copy of the latter (which would be jamui here). But in this case, the form is etymologically justified and represents the expected form of the marker. In (6), however, the definiteness marker exhibits a monosyllabic form instead of the possible joje. The exact phonological form is difficult to determine, as the variants nedeloi praiaszokusioie $\left(\mathrm{DaP} 76_{40}\right)$ and PRaiaszókusioi nedeloi ( $\mathrm{DaP}_{21} \mathrm{1}_{37}$ ) both show divergent writings of the same marker. While such orthographic fluctuation could even be interpreted as pointing to a maximally reduced definiteness marker devoid of any inflectional material, the fact that other cells of the paradigm do show explicitly marked and identifiable forms makes this rather unlikely. ${ }^{23}$ In all the forms where a disyllabic form would be expected in principle, we find monosyllabic forms. As far as the evidence goes, there is thus good reason to believe that an internalization of disyllabic forms was at least disfavored if not impossible.

Note that these findings have an impact that goes beyond the realm of the definiteness markers. The optional dropping of [e] in inflectional endings in word-final position is a common phenomenon in Lithuanian, evenly occurring across all word classes, predominantly in plural forms of the verb and in locative case forms, cf. the (non-exhaustive) examples in table $3:^{24}$

23 A possible instance of a reduced marker in another case form might be the following:

(1) ußkietawusi schirdi tu

harden.PART.PRET.ACC.SG heart.ACC.SG DEM.GEN.PL pra-ghi-keiktu-iu $\quad \beta i d u$

PV-DEF-cursed.GEN.PL-DEF.GEN.PL Jew.GEN.PL

'the hardened heart of the cursed Jews' (WoP: 120r $_{5}$ )

However, ghi might be simply a scribal error for expected ghiu (as per Hock 2016).

24 The table presents Modern Lithuanian forms, which, however, can function as a proxy for older stages of the language as well. 
TABLE 3 Word-final loss of $e$

\begin{tabular}{llll} 
Grammatical information & Full form & Short form & Meaning \\
\hline$u$-stem loc.sg. & danguje & danguj & 'in heaven' \\
$i$-stem loc.sg. & širdyje & širdy & 'in the heart' \\
$a$-stem adj. loc.sg. & baltame & baltam & 'in the white (one)' \\
o-stem loc.sg. & knygoje & knygoj & 'in the book' \\
$a$-stem loc.pl. & miškuose & miškuos & 'in the woods' \\
1. person pl. & geriame & geriam & 'we drink' \\
2. person pl. & geriate & geriat & 'you drink'
\end{tabular}

As for the endings, at first glance it seems that the process could be described in terms of a phonological rule, i.e.: [e] can be optionally dropped in absolute final position within a certain domain, namely the word. However, the situation is more complex as, for example, the locative singular of the $a$-stems would be exempt from such a rule (cf. danguje and danguj 'in heaven; in the sky' as opposed to name 'in the house', but not "nam). To save this rule, one would have to posit a phonological domain "word ending" (i.e. stem ending plus inflectional material), for which there is little additional evidence, and then rephrase the rule with respect to this hypothetical domain and limit it to disyllabic endings (i.e. - uje but not -e). Considering the drawbacks of such an approach, it seems more sensible to locate the dropping of $[\mathrm{e}]$ in the sphere of morphonology.

This analysis is backed up by the evidence of the definiteness markers in internal position. Since the internal forms are not constructed by moving an element from word-final to word-internal position (see above), one cannot argue that first word-final phonological rules apply and then the element is moved to its internal slot. An account that operates with morphophonemic alternations in the inflectional endings, on the other hand, captures these variants independently of their position. Theoretically, one could assume a juncture between the internal definiteness marker and the lexical root of the word which would result in word-final phonology in this position within the whole word form. Evidence from finite verbal forms could be adduced to support this claim, but the fact that the inflectional endings do not easily lend themselves to a purely phonological approach tips the scales in favor of the morphophonological analysis presented here. What is more, some forms clearly show that phonological processes applying in word-final position did not operate on internal definiteness markers. 
The Knyga Nobažnystės features a form of the genitive singular of the masculine ne iokattoia 'not guilty' ( $\mathrm{KnN}_{2}{ }_{2}{ }_{25} 8_{16}$, see example (13) below), where the definiteness marker is represented twice: once after the negation as io and then again after the inflection of the adjectival stem as $i \dot{a}$. The latter shows a reduced form resulting from the shortening of [o], a strong phonological tendency in this text for word-final syllables in polysyllabic words. The internal marker, however, patterns with the inflection on the stem, both being protected from this shortening by virtue of being in non-final position. The consequences of this are twofold. On the one hand, it proves that the internal marker is indeed internal with respect to the phonological word as defined by this process and that there are no indications of a word boundary between this item and the stem. On the other hand, it shows that the final marker is part of the same phonological word domain as well, for were it a distinct word, being monosyllabic, it would have to be exempt from the reduction. Although evidence for the phonological status of the definite adjectives and their components in Old Lithuanian is sparse, all signs point towards assuming single-word status for these forms.

Contrary to phonological wordhood, which due to the difficulty of the material has received little attention in the literature, the grammatical word has already been dealt with to some extent, although studies usually have (for several reasons) not been explicitly couched in terms of grammatical wordhood analysis. Most of the ideas presented so far can easily be transposed to present-day terminology, albeit with the difficulty that almost all research devoted to the morphological makeup of the definite forms is conducted with a strong orientation towards diachrony, whereas the descriptive concept of the grammatical word is purely synchronic. Among the criteria in the test battery usually adduced for grammatical wordhood, which is assembled and (negatively) evaluated in Haspelmath 2011, mobility and interruptability are the ones that are crucial for an understanding of the definite adjectives in Old Lithuanian, since they clash with the rest of the criteria which provide a positive answer for status as a single grammatical word unit. The list comprises ten criteria:

1. Potential pauses

2. Free occurrence

3. External mobility and internal fixedness

4. Uninterruptibility

5. Non-selectivity

6. Non-coordinatability

7. Anaphoric islandhood

8. Nonextractability 


\section{Morphological idiosyncrasies}

10. Deviations from biuniqueness

Despite Haspelmath's explicit claim that these criteria, whether applied separately or taken together, do not serve as a test battery to single out distinct categories of word and affix crosslinguistically, applying them with the aim of establishing descriptive profiles of the behavior of grammatical forms in a single language needs no justification.

The first of these criteria ("potential pauses") is obviously difficult to apply to data from written languages in general and from historical stages of languages in particular. Consequently, indications whether pauses were possible before or (with internal placement) after the definiteness markers or not are absent. It is thus perfectly justified to adopt an agnostic stance or even dismiss this criterion as irrelevant for historical material, although in some cases one might be tempted to transfer evidence from present-day stages back to earlier times. In modern Lithuanian at least, which has of course abandoned the internal placement of -ji-, pauses between this item and the rest of the word form are not possible in everyday speech.

While here the non-applicability of the criterion arises from the specific characteristics of the data type, the problem with the second criterion ("free occurence") is of a structural nature. The definiteness markers in Old Lithuanian cannot occur on their own, so they clearly respond as affixes to this test. But this behaviour is rooted rather in function and semantics than grammatical formalities. Since such markers serve to single out referents, they cannot occur without linguistic material denoting that referent. In this case, it is the global characteristics of the class to which the item belongs that this criterion would illustrate, and not the morphosyntactic behavior of the item as such.

Similar structural difficulties arise with non-coordinatability, anaphoric islandhood, and the criterion of nonextractability. The non-applicability of the latter two to anything else than referring expressions, and therefore their unsuitability as a test for grammatical status, is highlighted in Haspelmath's paper and pertains to the definiteness markers as well. Non-coordinatability, however, is more complex.
(7) WIffagalif-is
amf3inaf-is
allmighty.NOM.SG.-DEF.NOM.SG eternal.NOM.SG.-DEF.NOM.SG
Diewe
God.voc.sG
'O allmighty eternal God!' $\left(\mathrm{ViC} 6 \mathrm{o}_{17}\right)$ 
Here, the definiteness marker appears on both adjectives of the noun phrase. But a repetition of the definiteness marker is not obligatory (contrary to what is claimed by Stolz 2007: 226-227 for modern Lithuanian, which does not differ essentially from Old Lithuanian in this respect), as is shown by (8):

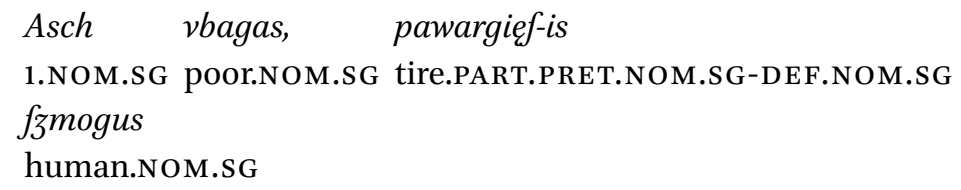

But this is more evidence against definiteness marking on the adjective as an agreement phenomenon than an argument for word status of the markers themselves, since it is the NP as a whole that has the function of establishing reference. There are cases, however, which are more intriguing. When two NPS consisting of a single adjective each are coordinated, the definiteness marker, just like a German or English article, need not necessarily appear on both NPs, even though both of them are to be read as definite, as is shown by the following example: ${ }^{25}$

(9) Ifch te ateis fuditu giwu ir

from there come.FUT. 3 judge.SUP alive.GEN.PL and numirufu-iu.

die.PART.PRET.GEN.PL-DEF.GEN.PL

'from there he will come to judge the living and the dead' (MžK 22 3 )

Here the first of the nominalized adjectives occurs without any overt marking of definiteness. This suggests that in coordination structures with nominalized definite adjectives, the definiteness marker can have scope over both elements of the coordination. The position of $-j i$-in such constructions is free and a realization on the first part of the coordination is equally possible, cf.:

(10) Sudźiu giwu-iu ir mirusiu judge.INST.SG alive.GEN.PL-DEF.GEN.PL and die.PART.PRET.GEN.PL 'as a judge of the living and the dead' $\left(\mathrm{SzP}_{\mathrm{I}} \mathrm{I} 4_{30}\right)$

25 Parenti (1995: 82-86) tackles the phenomenon from a syntactic perspective but lumps together NP-internal coordination of adjectives with reduction in coordinated NPs. This difference is, however, crucial. 
This means that the definiteness marker can not only be deleted under identity, but also that its placement with respect to the whole coordination is free, something that is unusual even for traditional clitics. But given the fact that definiteness marking in Lithuanian is essentially optional, as seen from examples where definite NPs are not marked at all, as in (11), perhaps such behavior is less surprising.

(11) Ifch te ateis suditu giwu ir from there come.FUT.3 judge.suP alive.GEN.PL and nůmirusiu die.PART.PRET.GEN.PL 'from there he will come to judge the living and the dead' ( $\left.\mathrm{ViC}_{18} 8_{8-9}\right)$

Deviations from biuniqueness are arguably the weakest criterion adduced to test wordhood status of a given element. However, it is interesting to note that in Old Lithuanian cases with doubling of the definiteness marker are possible. Doubling can occur either in the same position, that is two markers at the end of the word form, or in both possible slots, that is after prefixal elements and in final position (cf. Zinkevičius 1958: 8). Example (12) illustrates the former, (13) the latter:

(12) idant ant numirufu ir

that on die.PART.PRET.GEN.PL and giwu-iu-iu

Wiefchpatautu

alive.GEN.PL-DEF.GEN.PL-DEF.GEN.PL reign.SUBJ.3

'that he might be Lord both of the dead and living' (BrB Rom 14,9)

(13) walgit Awinelá ne io-katto-iä

eat.INF lamb.GEN.SG NEG DEF.GEN.SG-guilty.GEN.SG-DEF.GEN.SG

'to eat of the innocent lamb' $\left(\mathrm{KnN}_{2}{ }_{2} 258_{16}\right)$

Both Bretke's giwuiuiu and ne io-katto-iä in the Knyga Nobažnystės can be considered deviations from biuniqueness showing what has been termed multiple exponence in the literature, which means that a feature is realized twice within a given domain. This domain is restricted to the word in Harris (2017), who notes that clitics would represent a borderline case in her framework of multiple exponence (Harris 2017:9). Of course this results in rather fuzzy boundaries since the definition of multiple exponence thereby also hinges on the definition of the notion of "clitic", which as most recent research shows is laden with problems, the phenomenon under discussion being just another case in 
point. What is obvious, however, is that in both (12) and (13) there is a deviation from biuniqueness in that $-j i$ - encodes one and the same feature which is realized twice. If one takes the position of defending the affixal nature of the item in question, a natural analysis of example (13) would be to describe the definiteness marker as a circumfix to the domain of the unprefixed inflected stem. This would bring about quite unwelcome consequences, as in the typology of definiteness marking in Old Lithuanian one would have to set up a threefold classification of suffixes, prefixes and circumfixes. But the very fact that both parts of the putative circumfix can be omitted without any change in meaning (at least as far as the data goes) discourages us from taking this approach. Rather, we can conclude that here we are indeed dealing with true multiple exponence of the feature definiteness, which is essentially the same in both examples and only realized differently due to the diverging structure of the respective adjectives.

The question of mobility (of words) versus fixedness (of non-words), as has become clear from what has been laid out above, is of great significance for the grammatical characteristics of the definiteness markers in Old Lithuanian. As already illustrated in example (4), - ji- can be placed between prefixal elements and the stem, contrary to its usual placement at the very edge of the whole word form when there is no such prefixed material. ${ }^{26}$ That is, under the criterion of mobility, -ji- does not behave like an affix, but an independent grammatical word or clitic: it has potentially two slots available for its placement. This fact, while being remarkable in itself, is even more striking with regard to the structural position of one of these slots. It is perfectly normal for movable ("clitical") elements to occur at the outer boundaries of a given domain, but the placement inside of an otherwise closed domain is highly exceptional. Such elements have been baptized "endoclitics" in the literature. ${ }^{27}$ The introduction of these forms under the name of endoclitics into linguistic discourse has encountered a massive backlash defending the traditional theory of clitics, which rules out such clitic placement within words, and both single-word status of the host and clitic status of the intervening item have been denied. However, at least the behav-

26 This kind of mobility occurs with preverbs and prefixes only, and is therefore reminiscent of tmesis phenomena in Ancient Greek, so it might prove fruitful to adopt the term for Baltic grammar as well. It is consequently applied to the definite adjectives in Petit 2010: 301-302. But since in Greek the term implies a considerably larger degree of interruptability, I will avoid it in my discussion.

27 Some typologies (e.g. Velupillai 2012) set up two different types of word-internal clitic placement: endoclitics and mesoclitics, a distinction that has no consequences in most cases. Mathiassen (1996: 23) uses the term "endoclitic" in a rather confusing way to refer to clitics which can be placed before or after the host. 
ior of person agreement markers in Udi (Harris 2000, Harris 2002) has resisted such attempts (cf. Anderson 2005), to which now may be added the focus clitics of Chintang (Bickel et al. 2007). The concept of endoclisis has been restricted to these latter cases where items can be inserted into single-morphemic structures by Spencer and Luís (2012). However, a categorical distinction between endoclisis in this strict sense and related constructions can be upheld only with some difficulty, since e.g. in the respective languages the same items that under certain conditions can be inserted into roots are placed between composite elements of light verb structures as well. Although the two cases of course differ, separating them categorically seems undesirable. It is obvious that the behaviour specific to the definiteness markers in Old Lithuanian cannot be inserted into roots, for instance. In addition, the host has a clearly composite structure. On the other hand, there is no evidence for composite phonological form (as laid out above) and the host structure shows all the characteristics of a single grammatical Lithuanian word.

However, if one considers the definiteness markers to be internal not only in terms of linearization, which they certainly are, but also in terms of structure, one has to argue that these markers indeed differ from other linguistic items appearing in front of the root and are not simply prefixes themselves. ${ }^{28} \mathrm{~A}$ very simple argument is, of course, the position of these items in contexts without other prefixes where they occur after the inflection of the adjectival stem: If they were prefixes, they would have to be placed at the left edge of these forms. In theory, one could counter this by invoking something like an Optimality Theory account with ranked rules (inspired by Anderson 2005) and argue that the items are indeed prefixes, but are subject to a constraint disallowing initial placement in the word domain. This constraint would outrank the one placing them before the root. Still, such an account is not without complications, as it needs additional steps to account for the exact placement of the item, which would make the argument rather convoluted and therefore less attractive. Also, it would not explain the inflectional nature of the alleged prefix as it would be the only item of this class that inflects. In fact, this behavior makes the definite adjectives of Old Lithuanian problematic under another criterion for grammatical wordhood not included in the list compiled by Haspelmath. Wolfgang Wurzel adduced the following two defining characteristics of a morphological word (cited after the English translation of Stolz 2007: 220):

28 The ontological status of roots in the Baltic languages cannot be discussed here. In the present context, I use the term instead of "stem" to describe the position of the elements accurately and not to prejudice the question of whether the other prefixes are part of the stem or not and thus constitute some other subdomain of the word. 
1. A morphological word is a grammatical unit which cannot be interrupted by lexemes.

2. A morphological word is a grammatical unit the constituents of which cannot be inflected separately.

According to this definition, the definite adjectives in Old Lithuanian would consist of three grammatical words: the prefix, the definiteness marker, and the root plus its derivational and inflectional suffixes. ${ }^{29}$ Note that this analysis is the consequence of the definiteness marker's inflection, not its changing position, since Wurzel's definition seems to allow for permutability of elements within a grammatical word. While phonological processes, as discussed above, do not differ between the structural elements of the definite adjectives, the definiteness markers themselves have grammatical word status as inflecting and, to some extent, mobile items. To sum up, they exhibit properties strongly associated with clitics in most frameworks. In any case, they can hardly be included under the same heading as the prefixes. Rather, one has to consider them as elements which are indeed inserted into a domain formed by the prefix and the rest of the lexical stem. Again, the definiteness markers prove to be very evasive for attempts at a clear-cut binary classification. The terminological escape routes linguists have come up with in similar cases testify to these difficulties: Lithuanian reflexives have been called "Wackernagel affixes" (Nevis and Joseph 1993), Estonian indefinite pronouns "non-endoclitics" (Nevis 1984).

It is striking that all examples of endoclisis adduced in the literature are verbal in nature. The complex definite forms of Old Lithuanian, however, are an instance of a phenomenon that could be interpreted as endoclitic in nature from the nominal domain. Suspiciously, the lion's share of the forms are participles, that is adjectival forms closely associated with the verbal system. Among the examples cited in the literature, which can be considered nearly exhaustive, there are only two pure adjectives: the already discussed ne iokattoia $\left(\mathrm{KnN}_{2}^{1}\right.$ ${ }_{25} 8_{16}$ ) and páiopräftà 'simple' (GEN.SG.MASC, PeK 98 ${ }_{16}$ ). Both of these contain, at least on the surface, a suffix -ta-, which is also used to form verbal adjectives. As the name suggests, these adjectives are also intimately involved in the verbal sphere and under some accounts are taken to represent participles as well. The shape of formations like fuiefpaufti $\left(\mathrm{KnN}^{1}{ }_{15721}\right)$ could thus simply be due to this closeness to the verbal system. However, ne iokattoia and probably also páiopráfta resist this explanation. The latter could derive from

29 The number of morphological words might be reduced to two, depending on one's willingness to accept lexeme status for $-j i$-. However, the result would still be a discontinuous word. 
papràsti 'get used to', but even then its synchronic status as a participle would not be entirely clear. For ne iokattoia there is no such verbal base, so this form on any account has to be taken as an original adjective. This means that, although there is a significant preponderance, this pattern is not restricted to the verbal sphere, but has to be acknowledged for non-verbal forms as well. Word class aside, verbs and adjectives are nonetheless structurally similar in showing the reduced form of the prefix ("preverb") in cases where there is alternation, i.e. $p a$ - instead of $p o$ - and this generally must have favored internal placement. ${ }^{30}$ The fact that participles dominate in this category can be interpreted in two ways. First, it could result from the internal structure of participles, which more often provide a suitable host for internal placement of the definiteness marker than adjectives. Adjectives would then not be fundamentally different from participles and the observed data would merely be probabilistic. Second, there might well be diachronic underpinnings to this uneven distribution. In one version of a diachronic scenario, the internal pattern would have spilled over from participles to adjectives and thus would have witnessed a shortlived and sporadic productivity before it was abandoned altogether. A second possible development would be a decline of the internal placement of the definiteness markers starting in purely adjectival forms. Given the rarity of this low-frequency phenomenon, it is impossible to decide between all these possibilities. The internal pattern in adjectival forms is absent from Daukša, however, who writes e.g. nekattuoiú (inst.sg.masc, DaP $379_{2}$ ), not *neiuokattu, and páprastuoiu (inst.sg.masc, $\mathrm{DaP} 45 \mathrm{O}_{23}$ ), not * paiuoprastu. This favors an account which does not assume a structurally balanced situation between adjectives and participles. In other words, the pattern was either originally alien to pure adjectives or they were more prone to lose it at the time of the Old Lithuanian texts.

To sum up, one must emphasize that while internal placement of - ji-was by no means productive in Old Lithuanian, its importance for the phenomenology of definiteness marking is decisive. Internal marking was abandoned already within the later stages of Old Lithuanian, where the marker follows the inflectional ending of the adjective (or the remnants thereof) and there are no traces of it left in the modern language. I will address the interpretations these findings have met with in the literature below and turn now to the similarly important criterion of non-selectivity.

30 This point is rightly emphasized by one of the reviewers of this paper. Note, however, that this cannot account for the distribution as such, as reduced forms also occur with substantives, e.g. pamiškẽ 'edge of a forest'. 
Non-selectivity is one of the most widely used criteria for clitichood and thus grammatical wordhood, which is supposed to set off this class of items with their promiscuous attachment to all kind of hosts from the class of affixes, which can only attach to a more or less closely limited set of morphological hosts. It has been claimed almost unanimously in the literature that -ji-could indeed attach to other hosts than adjectives, namely adnominal case forms of nouns. Such a case is illustrated in (14):

(14) idànt anfäi daguieiis vkinikas níeko

that DEM.NOM.SG heavenly.NOM.SG lord.NOM.sG nothing.GEN.SG musímp pafmírdufsio, nieko dargaus

we.ADESS.PL stinking.GEN.SG nothing.GEN.SG unpleasant.GEN.SG niéko tamfaus, niéko akímus fáwo ne nothing.GEN.SG dark.GEN.SG nothing.GEN.SG eye.DAT.PL POSS NEG wérto ne pamatítu.

worthy.GEN.SG NEG see.SUBJ.3

'so that the heavenly lord see in us nothing stinking, nothing unpleasant, nothing dark, nothing unworthy to his eyes' ( $\mathrm{DaP}_{3313-15}$ )

The adnominal modifier daguieiis in (14) is usually analyzed as consisting of an inflected case form of a noun and an attached pronominal element (i.e. the definiteness marker) in the same case (here the locative singular of the masculine). ${ }^{31}$

But there are problems for such an analysis, at least in purely synchronic terms. On the level of morphology, the endings of the dative singular and adessive singular indicate that the speakers (or, more precisely, writers and readers) did not perceive these forms as containing a pronominal element (Hock 2016: 372-373, from which the following example is borrowed):
(15) Diew-uy Tew-uy fáwá-muy daguiei-uy god-DAT.SG father-DAT.SG own-DAT.SG heavenly-DAT.SG 'to god, his heavenly father' $\left(\mathrm{MoP}_{\mathrm{I}}: 195 \mathrm{v}_{41}\right)$

As this example shows, the ending of the modifier patterns with those of the nouns Diewuy 'god' and Tewuy 'father' and not the pronominal possessive fáwámuy.

31 These forms are not only important for the morphological behavior of the definiteness marker but have constituted a centerpiece in the argument for an alleged NP-building function of $-j i$-. I will address this aspect of the problem elsewhere. 
Semantics provide evidence against the traditional view as well, compare (16):

(16) ißwîdo kâtna pítna žirgu ir

see.PST.3 mountain.ACC.SG full.ACC.SG horse.GEN.PL and

weร̌imu vgniiu

chariot.GEN.PL fiery.GEN.PL

'and he saw a mountain full of fiery chariots and horses' ( $\left.\mathrm{DaP}_{522}{ }_{28-29}\right)$

Maskuliūnas (2000), who provides several examples, convincingly argues that nominal case in these forms is synchronically not to be analysed as such anymore. The example of ugnyjis proves this point clearly. Although historically deriving from ugny(je), the locative is deprived of all the spatial semantics associated with this case form and in synchronic terms serves only as the morphological base for the derivation. ${ }^{32}$

Another case in point comes from dialectal material. Here the very same data cited in support of a supposed attachment of the definiteness marker to nouns in fact turn out to prove exactly the opposite. In the dialect of Lazunnai, nominal attributive modifiers can appear in a shape resembling the definite form of adjectives, compare the oft-cited example (17a) and (17b) below:
a. dzievo-ji
'divine bee' (Arumaa 1930: 67, notation adapted)
b. $m a \check{z} o j i$
bite
small.NOM.SG.DEF bee.NOM.SG.FEM
'little bee' (constructed by the author)

bite

god.GEN.SG.MASC.-X.NOM.SG.FEM bee.NOM.SG.FEM

The similarity of (17a) and (17b) has led almost all scholars to assume an identity of the two elements and, consequently, promiscuity of -ji- with regard to host selection (e.g. Stolz 2010: 234). However, this is disproved by forms of the nominative singular of the masculine: here the adnominal nouns have - jis as in žuciüjis paũtas 'goose egg' (Petrauskas and Vidugiris 1985: 8), where the base to $-j i$-is the genitive plural of the word for goose. The definite adjectives, however, have -aĩ, cf. báltasai arklĩs 'the white horse' (Vidugiris 2014: 156). The alleged

\footnotetext{
32 Such operations can be classified as instances of hypostasis, a term introduced by Usener in 1873 (Mikkola 1962: 9-11).
} 
identity thus turns out to be mere superficial similarity. Functionally, the forms differ as well: the nominal forms serve to derive adjectives with inflectional potential from case forms, while the adjectival constructions mark definiteness on a given NP. The former thus operates on the level of NP-structure, the latter on the level of referential semantics.

Accordingly, the question whether the definiteness marker - ji- can attach to hosts other than adjectives must be answered in the negative. The type dangujejis should probably be disconnected from the definiteness marker: it has been shown that it differs functionally from the definite adjectives, and nothing compels us to assume identity of the two items. One is bound to adjectives and serves to mark definiteness, the other is a derivational suffix that builds adjectives from nominal case forms.

It might be argued that this analysis, even if true in terms of synchrony, must be incorrect from a diachronic point of view, as there is no derivational suffix - jis in Lithuanian. Note, however, that the inflectional class of inherited io-stems corresponds closely to such a suffix and also is highly productive in compounds, some of which can easily be traced back to hypostatic forms, e.g. bevaĩkis 'childless' $\leftarrow$ be vaĩko 'without child'. While the morphological operations to which the material is subjected are not identical—concatenative addition in one case, deletion of inflectional marking in the other-the two constructions are remarkably close in both form and function. This interpretation of the data seems preferable to transposing the idea brought forth for structurally parallel forms in Slavic by Aitzetmüller (1991: 131), for whom /j/ in these forms primarily had a hiatus-deleting function. ${ }^{33}$

The consequences of this are twofold. For morphology, this means that the definiteness markers do not attach to hosts other than adjectives, and most morphological theories would not consider them clitics as they fail a test that is often considered to be critical since Zwicky and Pullum's seminal paper on clitics (Zwicky and Pullum 1983). ${ }^{34}$

As I have shown above, the definiteness markers in Old Lithuanian do not lend themselves easily to an analysis relying on a binary classification of word and affix. On the one hand, they show features traditionally associated with affixes like idiosyncratic morphophonological interaction with their host, but

33 The ending of the feminine nominative singular - $j i$ attested in some Old Lithuanian forms can easily be attributed to influence from the definite adjective.

34 For the diachrony of the syntax of the noun phrase, we have to conclude that -ji- was a definiteness marker of noun phrases, hosted by the adjective from early on, and did not evolve secondarily from an element integrating attributive material into complex noun phrases. 
on the other hand they behave like grammatical words (i.e. clitics) in showing inflection and and not being bound to a single position with respect to their attachment site.

Already in the later stages of Old Lithuanian, the internal slot before the root was blocked for the positioning of the definiteness marker, which thereby lost one of the essential clitic-like features. The items thus became almost completely affix-like. However, one has to stress that this development is not something that "naturally had to happen". The other direction would have been equally possible. To provide an example: the Lithuanian focus marker $g i$ was an "affix-like clitic" which triggered the same morphophonological phenomena on the host as the definiteness marker, but in present-day Lithuanian it is a "pure" clitic passing all standard tests set up in the literature.

The same goes for invoking a crosslinguistic bias against endoclisis which prevents endoclisis from becoming productive. For an example from another language family one can look to endoclisis in Udi, which was not present in this form in the ancestor language Caucasian Albanian (Schulze 2015) and must therefore have spread rapidly during a short period of time to several morphosyntactic contexts and afterwards remained stable until the present, or it must have encroached slowly over a larger time span to ever new domains. In any case, it surely was a diachronically motivated process and not some morphological accident, brought about by an unfortunate series of events in the language. If I am correct in my analysis above by assuming that the endoclitic pattern spread from participles to other adjectives, a similar productivity has to be inferred for Old Lithuanian, although on a far more modest scale and with only a short life span.

\subsection{Latvian}

Like Lithuanian, Latvian has a fully developed adjectival paradigm for marking definiteness on noun phrases containing adjectival modifiers. But the paradigm of definite adjectives in Latvian differs considerably from Lithuanian not only in the shape of the items in single cells but in the general principles of formation underlying its morphological design, notably with respect to segmentation of units. In modern standard Latvian, adjectives inflect as shown in table 4 .

As a comparison of table 4 with table 1 shows (see p. 182 and p. 158 respectively), the main differences between Lithuanian and Latvian can easily be formulated. While Lithuanian mainly relies on a concatenative strategy for forming the definite adjectives (see above), Latvian does so to only a very restricted extent. Petit (2009: 321-322) sets up two synchronic rules by which the forms of the definite paradigm can be derived from their simple counterparts: 
TABLE 4 The inflection of Latvian mazs 'little'

Case

Masculine

Feminine

$\begin{array}{lll}\text { Singular } & \text { Plural } & \text { Singular }\end{array}$

Simple Definite Simple Definite Simple Definite Simple Definite

\begin{tabular}{lllllllll} 
Nom. & mazs & mazais & mazi & mazie & maza & mazā & mazas & mazās \\
Gen. & maza & mazā & mazu & mazo & mazas & mazās & mazu & mazo \\
Dat. & mazam & mazajam & maziem & mazajiem & mazai & mazajai & mazām mazajām \\
Acc. & mazu & mazo & mazus & mazos & mazu & mazo & mazas & mazās \\
Loc. & mazā & mazajā & mazos & mazajos & mazāa & mazajā & mazās & mazajās \\
\hline
\end{tabular}

1. If a simple form ends in a short vowel, the definite form is obtained by lengthening that vowel, e.g. gen.sg.masc. maza $\rightarrow m a z \bar{a}$.

2. If a simple form ends in a long vowel, the definite form is obtained by inserting a suffix -ai- (before consonants) or - $a j$ - (before vowels) before the ending, e.g. nom.sg.masc. mazs $\rightarrow$ mazais, dat.pl.fem. mazām $\rightarrow$ mazajām.

The two rules can be conflated into the following statement: To produce the definite form, lengthen the vowel of the corresponding ending. If this is not possible, either because the vowel of the ending is already long or because there is no vowel to lengthen, insert -ai- before the ending. While both rules would need some further specifications, ${ }^{35}$ what they capture nicely is that there are two different morphological principles at work, which result in a different locus of definiteness marking. It is reasonable not to interpret - $a j$ - as an infix inserted into inflected forms as bases. But the question needs to be addressed how to segment these forms, that is, whether the item belongs to the ending or to the stem. At first one might be tempted to assign -aj- to the ending for systemic reasons, since definiteness is marked on the ending in the majority of forms and the morphological operation could be given a unified abstract account with a phonological emphasis: mark definiteness by lengthening the inflec-

35 The first rule must specify that the output of the lengthening process in the cases of [i] and $[\mathrm{u}]$ is [ie] and [uo] respectively, not [ī] and [ū]. The second rule has to assume diphthong status for $[\mathrm{am}]$. Also, the relation between $-a i$ - and $-a j$ - has to be specified, since if the latter represented the underlying form of the former, one would expect an ending -aiš in the nominative singular of the masculine, as some dialects in fact have. 
tional ending, either by elongation of the vowel or by adding an additional syllable. However, the forms with -aj- easily lend themselves to an analysis in terms of compositionality, as this item is a clearly segmented unit associated with a clearly determinable meaning, and can thus be assigned to the stem.

The implications of this analysis are that the locus of marking in Latvian switches from ending to stem and back to the ending within the paradigm. Furthermore, we have to classify the paradigm as showing stem suppletion: mazand mazaj- in the example of table 4. Under the assumption of the split morphology hypothesis (see Anderson 1992 among others), which sees derivation as belonging to the lexicon and inflection as being part of the grammar, the category of definiteness in Latvian must then be split along this divide as well. Suppletion of this type is also something that is not very common in Latvian (with of course the notable exception of the verbs 'to be' and 'to go'), ${ }^{36}$ which makes the paradigm of the definite adjectives also remarkable with respect to grammatical structure within the context of the language's morphological makeup. In fact, for all the forms with - aj- there exist secondary forms without this element (Endzelin 1923: 345). This suggests that the pattern with marking on the ending in some forms but on the stem in others was felt to be inconvenient and therefore replaced by a more homogeneous strategy, even at the cost that the new forms without - $a j$ - did not differ from the corresponding indefinite simple forms.

After this synchronic description and classification and the consequences thereof, I now turn to the history of definiteness marking on the adjective in Latvian which gave rise to the paradigm in table 4. Rather than aiming at an explanation of the paradigm on a cell-by-cell basis with as much regularity of sound change as possible and invoking instances of irregular shortening and analogy for the rest (like e.g. Forssman 2001:132-133), I find an approach which looks for overarching tendencies of development to be more promising. Forssman (2001: 131) states that the development was not always lautgesetzlich, but it would be difficult to argue for the Lautgesetzlichkeit of even a single form in the whole paradigm. According to Endzelin 1902, the dative singular of the feminine shows a regular development of *mazaijai > mazajai, but evidence which would support this claim is lacking, as Endzelin himself admits.

The starting point of the diachronic development is understood to be a stage represented more or less faithfully by Old Lithuanian, which is basically—and

36 Another case in point is the relation between adverbial daudz 'much' and vairäk 'more'. But even if this is taken to be a paradigmatic relation, it nonetheless is of a lexical type-as is 'to be', too-and thus different. 
to a large extent justifiably-projected back not only to Proto-Eastern-Baltic but to Proto-Baltic (see below for Old Prussian). However, most dialects of Latvian and the standard language do not have an independent pronoun jis, ji. ${ }^{37}$ Also, denominal forms like Old Lithuanian dangujejis (for which, however, see above) are absent from all stages of the language. The picture shown by Latvian is thus usually interpreted as being a more "advanced" version of a path already entered upon by Lithuanian (e.g. Forssman 20o1: 131). It is important to note that such an approach emphasizes the historical connections between the two languages and furthermore assumes two things: first, a continuous and specific unidirectional trajectory of development and second, an inescapability of the underlying processes of language change. It is worthwhile to test these assumptions against the actually attested data. ${ }^{38}$

In the documented history of Latvian, the definite adjectives exhibit forms deviating from what we see in the modern language. Usually these are, not surprisingly, seen as the forerunners of today's paradigm in the sense just elaborated on. Bielenstein in his grammars gives two paradigms of the definite inflection: one labeled "uncontrahiert" and the other "contrahiert" (Bielenstein 1863: 84-87, Bielenstein 1864: 53-6o). The latter corresponds to the paradigm of today's standard language, with the locative and dative forms being represented by the short forms without - aj-. The other paradigm, on the other hand, has this segment (or, more precisely, a lengthened variant of it) in all cells. Compare the inflection in table 5 below. ${ }^{39}$

What emerges from a comparison of the definite adjectives in table 5 with the ones in table 4 (replacing the datives and locatives with the $a j$-less variants) is that the two paradigms employ completely different strategies to mark definiteness. From table 5 it is possible to extract a stem mazāj- to which the regular endings of the adjectives are then added. The only exception is the nominative singular of the masculine, where according to this rationale *mazājš or *mazājs would have been the expected form. This type of definite

37 I am not making any claims concerning possible relics of earlier, i.e. unattested, stages of Latvian, which are preserved in other lexemes or functional words.

38 I do not dispute the primacy of the Lithuanian data, which are undeniably structurally closer to-but not identical with - what we have to reconstruct for Proto-Baltic than the Latvian forms. The point of the following paragraphs is rather to see what picture emerges if Latvian is primarily approached on its own terms. I will address the prehistory of the definite adjectives in Baltic elsewhere.

The paradigm is from Bielenstein 1864: 58. For the sake of exposition, I have changed the example lexeme from labs 'good' to mazs 'small' and adapted the notation according to modern orthography. Note also that Bielenstein segmented the forms in keeping with his view on their genesis and attributed the $-j$ - to the ending. 
TABLE 5 Latvian definite adjectives with generalized stem in $-\bar{a} j$ -

Case Masculine $\quad$ Feminine

Singular Plural Singular Plural

\begin{tabular}{|c|c|c|c|c|}
\hline Nom. & mazājis & $m a z a \bar{j} j i$ & mazāja & mazājas \\
\hline Gen. & mazāja & mazāju & mazājas & mazāju \\
\hline Dat. & mazājam & mazājiem & mazājai & mazājām \\
\hline Akk. & mazāju & mazājus & mazāju & mazājas \\
\hline Loc. & mazājāa & mazājos & $m a z \bar{a} j \bar{a}$ & mazājās \\
\hline
\end{tabular}

adjective in Latvian thus shows a clear strategy of marking definiteness on the adjective: the stem of the simple adjective is used as a base to which a dedicated suffix is then added, and the output is afterwards inflected as a normal adjective. ${ }^{40}$ Modern Standard Latvian represents a compromise between these two types, with the consequences mentioned above. This fact alone suggest that a purely teleological interpretation of the data, assuming a straight and unidirectional development, is misleading.

It is important to stress that the short forms cannot be derived from the ones in table 5 in a regular and direct way. Evidence from Old Latvian corroborates this as well. In Adolphi's grammar, the paradigm for the definite adjectives differs from both the modern and Bielenstein's versions, but is closer to the latter in showing - $a j$ - in all forms, with the rather strange exception of the accusative singular of the masculine. The endings, however, are short in some forms, but long in others. The genitive of the singular of the masculine is labbaja and thus has the regular ending - $a$ of the genitive. The plural, on the other hand, is labbajo, where - $o$ contrasts with $-u$ of the regular inflection (for the full paradigm see Pokrotniece 2002: 155).

There is, however, another part of speech which closely resembles the type of table 4 and Old Latvian forms like labbajo in its inflection, namely, the (demonstrative) pronouns.

40 This strategy thus differs essentially from the one employed by some Lithuanian dialects in various guises, where there is a tendency to use derivation of secondary stems as well (as reported by Kazlauskas 1972). But in Lithuanian there are still special sets of endings which differ from the usual adjectival inflections and furthermore morphophonologically interact with the stem in an often highly idiosyncratic way. 
Case

Masculine

Singular
Feminine

Plural

\begin{tabular}{|c|c|c|c|c|}
\hline Nom. & tas & tie & $t \bar{a}$ & $t \bar{a} s$ \\
\hline Gen. & $t \bar{a}$ & to & $t \bar{a} s$ & to \\
\hline Dat. & tam & tiem & tai & tām \\
\hline Acc. & to & tos & to & $t \bar{a} s$ \\
\hline Loc. & $\operatorname{tajā} /$ tai / tanī & tajos / tais / tanīs & tajā /tai / tanī & tajās / tais / tanīs \\
\hline
\end{tabular}

The paradigm of the pronominal inflection, here exemplified by tas in table 6, shows that there is almost complete agreement between the inflectional endings of tas and the definite forms of mazs. The only form that differs is again the nom.sg.masc. While there are some correspondences between pronouns and simple adjectives as well, the agreement between the former and the definite adjectives is clearly systematic. The forms of the pronominal inflection are indeed regular from the perspective of sound change (allowing, of course, for some minor analogical adaptations from the nominal system). It is thus reasonable to claim that the inflectional endings of the pronominal system were transferred to the definite adjective. However, it is usually argued that the form taja $\bar{a}$ in the locative is thought to be taken over from the definite adjectives. ${ }^{41}$ Equally possible is of course a extension of the more archaic tai by the very common ending $-\bar{a}$. But even if the first analysis holds true, it indicates that there was a close interaction between the paradigms of the definite adjective and the pronouns, albeit not entirely unidirectional in this case, which aimed at harmonizing the two.

The reason for this assimilation of the paradigm of the definite adjective to that of the demonstrative pronoun can be sought in syntax. Contrary to Lithuanian, the use of a demonstrative in a complex noun phrase containing an adjective enforces the use of a definite form of the latter (Holvoet and Spraunienè 2012: $73^{-76)} .^{42}$ This means that the definite inflection on adjectives is

41 The overabundance of forms in the locative is explained by Endzelin 1923: 387-389 (followed by Stang 1966: 241 and Forssman 2001: 146) as being the result of analogies and hybridization, which led to several forms existing side by side.

42 But not vice versa: the definite adjective does not automatically trigger the use of an additional D-element. The directionality of the dependence is thus clear. 
not completely autonomous since to some extent it depends on the demonstratives and is strongly associated with them, so that the two elements often occur together. This created an optimal environment for the transfer of the endings and led to a dedicated strategy of marking definiteness on the ending of adnominal modifiers.

\subsection{Old Prussian}

As for Old Prussian, research on adjectival definiteness marking in Baltic has by and large neglected this language, mainly due to lack of data, which has been interpreted as either a sign of almost complete loss of the distinction between the two inflections in the language (e.g. Trautmann 1910: 247) or attributed to imperfect language competence on behalf of the translator(s) of the texts (Endzelin 1944: 105).

However, notwithstanding this sparseness of material, the fact that Old Prussian possessed this double type of adjective inflection is of great importance for the chronology of the rise of this phenomenon in Baltic. From a purely morphological perspective, it is clear that Old Prussian considerably restructured its system of definiteness marking on adjectives, although it is not possible to establish a complete paradigm for the definite inflection. Only the forms of the accusative preserve some of the presupposed transparency. Old Prussian sides with Latvian against Lithuanian in that it does not feature an independent pronominal element ${ }^{*} j i-.^{43}$ Also as in Latvian, there are—synchronically speaking - no traces of the attachment of a clitic element to an inflected form of the adjective. The relevant forms are given in table 7 below. ${ }^{44}$

The forms in table 7 show that on a paradigm level, the formation of the definite adjective is not built up by more or less decomposable units as in Lithuanian. What is more, several formations, except for the nominative singular feminine, which seems to have served as the model for the masculine, underwent substantial remodeling of their morphology. The nominative singular masculine in -ois is, according to the traditional explanation, a replacement of the original ending by a wholesale transfer of the respective form of the feminine -oi enlarged by an additional $-s$, the appropriate case marker for this cell of the paradigm. The similarity of Old Prussian pirmois with Latvian pirmais is purely accidental in nature. In Latvian, a secondary stem-like formation ( pirmaj-) might have spread from the dative singular of the masculine (pirmajam), where it originated as the result of morphological reduction in a

43 Eastern Latvian dialects do possess a pronoun jis, ji for the 3 rd person. Conversely, some Lithuanian dialects have replaced jis, ji with former deictic demonstratives.

44 See e.g. Endzelin 1944: 104-106 for discussion. 
TABLE 7 The definite adjective in Old Prussian

\begin{tabular}{|c|c|c|c|c|}
\hline Form & Attestation & Noun phrase & Meaning & Text \\
\hline Nom.sg.fem. & pirmoi & Stai Pirmoi Maddla & 'the first prayer' & III 4714 \\
\hline Nom.sg.mas. & pirmois & Stas Pirmois Pallaips & 'the first commandment' & III 275 \\
\hline Nom.sg.mas. & pirmonnis & Stas Pirmonnis Dellijks & 'the first article' & III 3916 \\
\hline Acc.sg.mas.-nt. & pirmonnien & En Pirmonnien & 'first' & III $89_{3}$ \\
\hline Acc.sg.mas. & pirmannien & en pirmannien laisken & 'in the first book' & III $1 \mathrm{Ol}_{7-8}$ \\
\hline Nom.sg.mas. & dengenennis & mais Dengenennis Tāws & 'my heavenly father' & III $49_{20}$ \\
\hline Nom.sg.mas. & dengnenniffis & mais Dengnenniffis Taws & 'my heavenly father' & III 7911 \\
\hline
\end{tabular}

reconstructable * pirmamjam (cf. Forssman 2001: 132, but see above). But in Old Prussian the preconditions leading to such a process were not present, as the dative ending was -asmu (cf. wargasmu 'evil' III 3311). It seems thus best not to treat -oi- as a secondary stem-building element.

The motivation for this replacement in the nominative of the masculine, according to Mažiulis 2013: 715 and others, is a supposed syncretism of the definite form and the simple form, which arose due to the reduction of unaccented word-final vowels in Old Prussian. However, there is no positive evidence to substantiate these claims. In a reconstructable preform "pirmasis, the thematic vowel was shielded from the reduction process by an additional final syllable, which in turn underwent reduction, thus yielding pirmas. There is one attestation of pirmas in I 52 , which notwithstanding its German original "Das Erste", pointing to a definite reading, is supposed to represent the indefinite form, mostly due to the fact that it was corrected to pirmois in II 52 . There are two reasonable possibilities of interpretation. First, it could be argued that this sole attestation of pirmas does in fact represent a definite form not preserved elsewhere and that it was being replaced at the time of the Old Prussian monuments. Another possibility, which is the one usually entertained in the literature, is that orthographic pirmas represents phonological/pirməs/ with a secondary svarabhakti development to break up the final consonant cluster, and thus must be considered the indefinite form. But in this case a definite form with full vocalism (i.e. /pirmas/) would still contrast with simple /pirməs/, so that the reason for the restructuring is probably not to be sought within the domain of phonological developments.

The accusative pirmannien is equivalent to Lith. pirmaji and thus is etymologically regular. The second attested form pirmonnien is supposed to be a true variant (i.e. not an aberrant orthographic representation) and is said to repre- 
sent an underlying *pirmŭnis (Mažiulis 2013: 715). This would make pirmonnien a morphological blend of pirmois and pirmannien. But there is in fact a simpler explanation which allows one to reduce the variation to mere orthography: in several cases, $\langle 0\rangle$ shows up where etymology ensures [a], which is usually written as $\langle a\rangle$. The rationale behind the distribution of $\langle 0\rangle$ in these cases is not entirely clear (Rinkevičius 2015: 91-92). The same goes for the vocalism of the second syllable of pirmonnis. This form, however, is interesting insofar as it shows the same tendency as pirmois, namely, the secondary replacement by a form modeled on another cell of the paradigm. Structurally, the processes that led to these two forms differ. While pirmois took pirmoi as a ready-made input for its formation, pirmonnis arose in analogy to a reanalyzed accusative pirmannien. Here the internal case marker -an underwent reinterpretation as part of the inflectional stem to which the ending, the former inflecting marker for definiteness, was attached. What is obvious is that the result of this restructuring in the pirmonnis type is a shift of the locus of marking from the word-final inflectional slot to the newly built stem. While the change is, on the one hand, purely internal as it takes the cell of the accusative singular as its starting point, it is, on the other hand, in a way reminiscent of the weak inflection in High and Low German, which were the main contact languages of Old Prussian at the time of the texts. From a structural aspect this similarity is only superficial. The Old Prussian form can be analyzed as a suffixed derivative, i.e. as a derived stem, to which inflectional endings attach. In contemporary Low German and Early New High German, however, such a segmentation of the secondary stem and the ending is not possible for the weak inflection. What we are left with is a phonological resemblance between the ending of the German weak adjective and the derivative suffix in Old Prussian. This phonological similarity might of course have acted as a facilitating factor for the rise of the pirmonnis type, but given the scarcity of the data, it is not possible to further assess the eventual influence of German on the restructuring of the morphological makeup of the definite adjective in Old Prussian.

Finally, deng(e)nennis ${ }^{45}$ belongs to the pirmonnis type, i.e. the nominative corresponds to an unattested accusative ${ }^{*}$ dengen-en-ien. ${ }^{46}$ The adjective is instructive in another respect as well: it seems that even this new stem of the definite adjective was in need of reinforcement. First, dengnenniffis shows a doubling of the ending, which suggests a cyclical development of definiteness

\footnotetext{
45 All four attestations of deng(e)nnenis (III 4920, III 4911, III 81 11, III 8314) are used in vocative contexts, with the head noun tāws showing either the ending $-s$ of the nominative or $-a$ of the genuine vocative.

46 Petit (2009: 325) and Mendoza (2015: 174) consider this form to be indefinite.
} 
marking. However, this would presuppose that $-i s$ in itself was still associated with definiteness, for which there is little evidence. In addition, it is possible that the form is a typographical mistake (cf. Mažiulis 2013: 118). Second, the stem of the definite adjective dengenen- fed into word formation, as evinced by the form dengenneniskans (acc.pl.) 'heavenly' as well as dengniskans which are both derived from primary adjectives via the secondary suffix -iskas-.

As for the morphosyntax of definiteness in Old Prussian, it is clear that a definite reading of a given NP containing an adjectival modifier did not enforce the use of the definite form of the adjective, compare (18):
(18) ftas
wargs prēifiks
the.NOM.SG evil.NOM.SG enemy.NOM.SG
'the evil fiend' (III 7920)

Examples of the article in combination with the definite adjective are absent from the Enchiridion, but there is an attestation in the Second Catechism:
(19) ftae
neuwenen
Teftamenten
the.NOM.SG new.NOM.SG testament.NOM.SG 'the new testament' (II 1317)

In the Enchiridion the corresponding NP has an indefinite nauns: ${ }^{47}$
(20) ftas
nauns
Teftaments
the.NOM.SG new.NOM.SG testament.NOM.SG
'the new testament' (III 7510)

The complete absence of this combination from by far the largest Old Prussian text is remarkable, and cannot simply be attributed to a combination of the relatively low frequency of suitable contexts and the facultative nature of the definite adjective. A natural question arises as to if the picture might be interpreted in terms of diachrony. This necessarily touches upon the status of the article in Old Prussian as represented by the translation of the Enchiridion. It is still often claimed that the article of the translation is something completely foreign to the language itself and that it made its way into the texts because of the word-for-word character of the translation (Endzelin 1944, Rinkevičius 2015: 129). Parenti (1995) has, however, convincingly shown that an article has

47 Note that the noun 'testament' switched from neuter to masculine. 
to be assumed for Old Prussian beyond the texts of the translations as well. As already pointed out by Michelini (1989), the cases where the article of the German text is not translated conspicuously occur in the context of prepositional phrases. Compare example (21), where the article of the German prepositional phrase nach dem effen is dropped in Old Prussian:

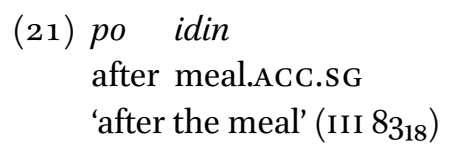

Michelini is inclined to view the deviations of the Old Prussian from the German text as cases of "true" Old Prussian, which he supposes to not have had a means for marking definiteness, contrary to the texts of the translation, which used demonstratives to make up for the lack of true D-elements. But Parenti (1995) rightly emphasized that prepositional constructions are exactly the contexts which, from a typological point of view, very often resist the use of articles in languages which otherwise employ articles to mark definiteness, or behave differently from other constructional environments. ${ }^{48}$ In diachronic developments, articles make their way into prepositional phrases only at later stages of a hypothetical grammaticalization path. However, the peculiarity of some German prepositions to fuse with some forms of the definite article can be mentioned as a counterargument for a similar situation in Old Prussian, the idea being that a fused combination of article and preposition represented a considerably weaker cue for the translator to use an article in his Old Prussian text. The following two examples serve to illustrate this problem:

(22) En-dangon

in-heaven.ACC.SG

'in heaven' (e.g. III 476)

(23) en ftan dangon

in DEM.ACC.SG heaven.ACC.SG

'into heaven' (III 5711-12)

For (23) the facing German has im Himel, with fusion of preposition and article, while (22) corresponds to inn den Himel, where no fusion is possible. Note

48 On articles and adpositions, see also Himmelmann 1998. 
TABLE 8 Articles in Old Prussian PPS

\section{German Translated Untranslated}

\begin{tabular}{lrr} 
Fused & 5 & 64 \\
Not fused & 63 & 14 \\
\hline
\end{tabular}

that in Old Prussian the case does not differ according to locative or directive employment of the preposition as it does in German. But that such differences in the German text were not the decisive factor for omitting the article is suggested by phrases where Old Prussian uses an article despite a fused form in the original:
(24) bhe aft
tennan Skijftinnons,
pra-ftan
and be.PRs.3 them purify.PART.PRET.NOM.SG through-DEM.ACC.SG vndas fpagtan èn-ftan wirdan water.GEN.SG bath.ACC.SG in-DEM.ACC.SG word.ACC.SG 'and has purified them by the bath of water in the word' (III 1039-10)

The corresponding German runs: vnd hat fie Gereiniget, durch das Wafferbad im Wort. While the first of the German articles is clearly discernible, the second is fused with the preposition (im Wort = in dem Wort) without any boundary between the two items, just as in (22). But in both cases, the German article is faithfully rendered by its equivalent in Old Prussian. The general picture, however, suggests that the placement of articles in Old Prussian prepositional phrases was not completely independent of the German (Parenti 1995: 85), as can be seen from table 8,49 where Fisher's exact test results in a significant value of $\mathrm{p}<0.005$. But note that the picture can be blurred, at least to some extent, since fusion in article-preposition combinations in German is not without semantic underpinnings and the Old Prussian article might be subject to very similar semantic constraints. Note also that the translator very often, but not consistently, writes Old Prussian preposition-article combinations as a single word without spatium, e.g. praftan, ēnftan.

Another important case in point where Old Prussian deviates from German is article deletion in coordinations:

49 The numbers are taken from Parenti 1995: 85 as well. 
(25) ifquendau tāns pergūbons wijrft, prei

thence 3SG come.PART.PRET.NOM.SG become.PRES. 3 to

ligint ftans gijwans bhe aulaufins.

judge.INF DEM.ACC.PL alive.ACC.PL and die.PART.PRET.ACC.PL

'from there he will come to judge the living and the dead' (III 435-7)

Here German has two articles: die Lebendigen vnd die Todten. All four renderings of this phrase in the Old Prussian corpus ${ }^{50}$ are alike in having only one D-element at the very first position of the coordination. That these parallel passages differ in another respect, namely word order in the matrix clause and copying of German $z u$ plus infinitive, ensures the authenticity of the definiteness marking even more. If we compare the Old Prussian of (25) with the Old Lithuanian structures of (9)-(12), we observe an interesting conformity. In both languages the underlying structure allows deletion of elements under identity, although the morphological means for marking definiteness differ. It must remain unclear if wide scope in Old Prussian was independent of directionality as it was in Old Lithuanian.

Another context in which Parenti (1995) detects a regular absence of the article are adnominal modifiers marked by the genitive. In the Second Catechism, these go without articles:

en emnen Thawas bho sounons bhe swyntas
in name.ACC.SG father.GEN.SG and son.GEN.SG and holy.GEN.SG
naseylis
spirit.GEN.SG
'in the name of the Father, the Son, and the Holy Spirit' (II 1114)

In the Enchiridion, on the other hand, these forms usually receive the article:

(27) en Emnen steise $\quad$ Täwas bhe steise
in name.ACC.SG DEM.GEN.SG father.GEN.SG and DEM.GEN.SG
Saūnas bhe steise Swintan Noseilīs
son.GEN.SG and DEM.GEN.SG holy.GEN.SG spirit.GEN.SG
'in the name of the Father, the Son, and the Holy Spirit' (III 5915-17)

Beside (27), the formula occurs three times in the Enchiridion (III $71_{19-20}$, III $107_{20}-109_{2}$, III $129_{10-12}$ ) and in each case there is some slight variation, but

$5^{\circ}$ In addition to example (25) these are: I 93-5, II 93-5 and III 12715-16. 
all of them show the same distribution of the article. While there are some exceptions, where the article is omitted from the translation, there is thus good reason to assume that the article did make its way into a new morphosyntactic domain.

To sum up, what is clear is that, even though the usage of the Old Prussian article is to some extent dependent on the German original of the Enchiridion, its deviations obey some systematic regularities and are not randomly distributed across different contexts. Furthermore, the evidence suggests that at the time of the texts the article was already firmly rooted in the language, but its spread to new domains was not yet completed. This means that Old Prussian used the D-element $f$ tas as a default means to mark noun phrases as definite and did not just copy the German on a purely textual level. Thus, the language had a deeply entrenched definiteness marker at hand which could be used independently of strong morphosyntactic constraints. The consequences for the definite adjectives of Old Prussian seem to have been that the article was on its way to ousting the definite forms of the adjective from the language completely. This process was probably additionally facilitated by the fact that the inflection of adjectives had undergone syncretistic simplifications. ${ }^{51}$

The rise of the article in Old Prussian can safely be attributed to language contact with Low and High German, i.e. a form of pattern borrowing. This is not to say that these languages were necessarily the source of the construction, but in any case, given the general impact they had on Old Prussian, they must have at least acted as a strong catalyst for the development of a dedicated Delement in Old Prussian. With Old Prussian, we therefore witness a case where language contact indirectly led to the decline of a morphological category (the definite adjectives) by giving rise to a competing strategy (the article). Old Prussian here fits into the larger areal picture constituted by the eastern border of the West Germanic language area, where the articles of languages like German fostered the development of D-elements in languages which until then had not made extensive use of morphosyntactic definiteness marking. However, Old Prussian went much farther than most other languages in the area in establishing a system that must have been indeed very close to Low and High German in almost losing an inherited strategy for definiteness marking. How close the usage of D-elements actually was can unfortunately not be reconstructed, given

$5^{1} \quad$ I assume that the patterns observed in the Enchiridion are at least partially rooted in actual language usage and not merely errors of the translator. For another view on this point, see Petit 2007. 
the nature of our texts. A parallel in geographical space and genetic affiliation (but not exactly time) comes from the Latvian dialect on the Curonian Spit (Nehrungskurisch). Here the use of D-elements also spread widely, but it did not precisely correspond to German. Interestingly, in Nehrungskurisch the definite inflection, while still being recognizable, suffered reduction to some extent as well (El Morghabel 1993).

\section{4}

\section{Conclusions}

It has become clear that the morphological developments of the definite adjectives differ remarkably in all three of the attested Baltic languages. Contrary to what is often believed in the field, such developments in the different branches do not simply represent different stages of one and the same unidirectional and predetermined development, insofar as Lithuanian would faithfully reflect the situation of Proto-Baltic and Latvian would be simply innovative. Rather, different factors interacted to produce different morphological constructions building on the same inherited material, namely the combination of an inflected adjective with an inflected marker for definiteness. At least from a morphological vantage point, the definite adjectives in the three languages are not merely instantiations of one underlying morphosyntactic type but rather constructions in their own right. An interesting contrast is the inverse correlation of formal morphological robustness and functional usage in Eastern Baltic. Whereas Lithuanian has preserved some traits of the original morphological structure faithfully, the definite adjective is far less entrenched in actual usage than in Latvian. With respect to meaning, however, both constructions remain close. $^{52}$

While Latvian definite adjectives seem to be quite straightforward at a first glance, the distribution of definiteness marking between ending and stem is remarkable in the language. Furthermore, it is possible to find a well-motivated rationale behind the historical developments other than purely local phonological developments and analogical spread.

In Lithuanian, especially in the older stages of the language, the marking of definiteness defies traditional morphological classification outright. The specific grammatical and phonological shape of the combination of adjective and definiteness marker cannot be adequately captured in frameworks which

$52 \quad$ See Holvoet and Spraunienè 2012 for the marginal cases where Latvian usage extends to domains not available to the definite adjective in Lithuanian. 
assume binary categories of word and affix, but rather needs to be addressed in more sophisticated terms allowing for non-matching domains.

Old Prussian seems to have considerably reduced the use of definite adjectives, most probably under the impact of the newly arisen structure of marking definiteness on noun phrases by a NP-initial D-element corresponding to the article of High and Low German varieties, which must ultimately have served as the model for the construction. Interestingly, the stabilization and extension of the use of the definite adjective is attributed to the very same source in the case of Latvian (Forssman 2001: 271) so that one and the same stimulus has triggered completely opposite developments in the two languages. ${ }^{53}$ While the situation in Old Prussian data is, as usual, difficult to interpret because of the sparseness of texts, this general conclusion is nonetheless plausible.

\section{Acknowledgments}

I would like to express my gratitude to two anonymous reviewers whose comments have benefitted the paper considerably.

\section{References}

Aitzetmüller, Rudolf (1991). Altbulgarische Grammatik als Einführung in die slavische Sprachwissenschaft. 2., verbesserte und erweiterte Auflage. Freiburg im Breisgau: Weiher.

Anderson, Stephen R. (1992). A-morphous Morphology. Cambridge: Cambridge University Press.

Anderson, Stephen R. (2005). Aspects of the Theory of Clitics. Oxford: Oxford University Press.

Arumaa, Peeter (1930). Litauische mundartliche Texte aus der Wilnaer Gegend. Dorpat: Postimees.

53 A third way is presented by Lithuanian in East Prussia, which has developed articlelike structures without reducing the use of the definite adjective. See my upcoming article "Deutsch-litauischer Sprachkontakt und Morphosyntax-Zur morphologischen Markierung von Definitheit in Preußisch-Litauen", which will appear in the proceedings of the conference "Minderheitensprachen und Sprachminderheiten: Deutsch und seine Kontaktsprachen in der Dokumentation der Wenker-Materialien, Marburg, 29.o2.03.03.2016". 
Bickel, Balthasar et al. (2007). "Free prefix ordering in Chintang”. In: Language 83.1, 4373.

Bielenstein, August (1863). Lettische Grammatik. Mitau: Fr. Lucas' Buchhandlung (Iwan Rochlitz).

Bielenstein, August (1864). Die lettische Sprache nach ihren Lauten und Formen erklärend und vergleichend dargestellt. Zweiter Theil. Die Wortbeugung. Berlin: Ferdinand Dümmler's Verlagsbuchhandlung.

Birkhan, Helmut (1974). "Das germanische starke Adjektiv”. In: Strukturen und Interpretationen: Studien zur deutschen Philologie, gewidmet Blanka Horacek zum 6o. Geburtstag. Ed. by Alfred Ebenbauer. Wien / Stuttgart: Braumüller, 1-24.

Cysouw, Michael and Jeff Good (2013). "Languoid, doculect and glossonym: Formalizing the notion 'language'. In: Language Documentation \& Conservation 7, 331-359.

El Morghabel, Christliebe (1993). Nehrungskurisch. Frankfurt am Main: Hector.

Endzelin, Jan (1902). "Zur Deklination der lettischen bestimmten Adjektiva”. In: Beiträge zur Kunde der indogermanischen Sprachen 27, 310-315.

Endzelin, Jan (1923). Lettische Grammatik. Heidelberg: Carl Winter.

Endzelin, Jan (1944). Altpreußische Grammatik. Riga: Latvju grāmata.

Falkenhahn, Viktor (1963). "Die Bedeutung der Verbalrektion für das Problem eines litauisch-polnischen Sprachbundes”. In: Zeitschrift für Slawistik 8.1, 893-907.

Ford, Gordon B. Jr. (1969). The Old Lithuanian Catechism of Baltramiejus Vilentas (1579). The Hague / Paris: Mouton.

Forssman, Berthold (2001). Lettische Grammatik. Dettelbach:J.H. Röll.

Grimm, Jakob (1848). Geschichte der deutschen Sprache. Leipzig: Weidmannsche Buchhandlung.

Harris, Alice C. (2000). "Where in the Word is the Udi clitic?" In: Language 76, 593-616. Harris, Alice C. (2002). Endoclitics and the Origins of Udi Morphosyntax. Oxford: Oxford University Press.

Harris, Alice C. (2017). Multiple Exponence. New York: Oxford University Press.

Harris, Alice C. and Jan Terje Faarlund (2006). "Trapped morphology”. In: Linguistics 42, 289-315.

Haspelmath, Martin (2011). "The indeterminacy of word segmentation and the nature of morphology and syntax". In: Folia Linguistica 45.1, 31-80.

Hill, Eugen (2014). "Inheritance and secondary similarities in the inflectional morphology of Baltic and Slavic". In: Baltai ir Slavai. Dvasiniu kultūrų sankirtos / Балты u славяне. Пересечения духовьх культур. Ed. by Tatjana Civjan, Marija Zavjalova, and Artūras Judžentis. Vilnius: Versmè, 177-195.

Himmelmann, Nikolaus P. (1997). Deiktikon, Artikel, Nominalphrase. Zur Emergenz syntaktischer Struktur. Tübingen: Niemeyer.

Himmelmann, Nikolaus P. (1998). "Regularity in irregularity: Article use in adpositional phrases". In: Linguistic Typology 2, 315-353. 
Hock, Wolfgang (2015). Altlitauisches etymologisches Wörterbuch. Vol. 1-3. Hamburg: Baar.

Hock, Wolfgang (2016). "Pronominierte Nominalformen im Altlitauischen". In: Indogermanische Forschungen 121, 365-386.

Holvoet, Axel and Birutė Spraunienė (2012). "Towards a semantic map for definite adjectives in Baltic". In: Baltic Linguistics 3, 65-99.

Kazlauskas, Jonas (1972). "İvardžiuotinių būdvardžių raida baltų kalbose”. In: Kalbotyra 24.1, 57-74.

Koch, Christoph (1992). "Zur Vorgeschichte des relativen Attributivkonnexes im Baltischen und Slavischen". In: Indogermanisch, Slawisch und Baltisch. Ed. by Bernd Barschel, Maria Kozianka, and Karin Weber. Otto Sagner, 45-88.

Leskien, August (1881). "Die Quantitätsverhältnisse im Auslaut des Litauischen". In: Archiv für slavische Philologie 5, 188-19o.

Maskuliūnas, Bronius (2000). "Vietinininkiniai būdvardžiai-archajinė senujų raštų posesyvumo raiškos priemonè”. In: Baltistica 35.2, 151-157.

Mathiassen, Terje (1996). "On clitics in Baltic”. In: Baltistica 31.1, 23-29.

Mažiulis, Vytautas (2013). Prūsu kalbos etimologijos žodynas. Antrasis pataisytas ir papildytas leidimas. Vilnius: Mokslo ir enciklopedijų leidybos centras.

Mendoza, Imke (2015). "Das baltoslavische lange Adjektiv und der Sprachkontakt". In: Wiener Slawistischer Almanach Sonderband 86, 173-187.

Michelini, Guido (1989). “Der Artikel im Altpreußischen”. In: Zeitschrift für Slawistik 34.2, 217-220.

Mikkola, Eino (1962). Die präpositionale Hypostase, Apostase und Metabase im Lateinischen, Griechischen und Altindischen. Helsinki: Suomalaisen Kirjallisuuden Kirjapaino Oy.

Nevis, Joel A. (1984). “A non-endoclitic in Estonian”. In: Lingua 64, 209-224.

Nevis, Joel A. and Brian D. Joseph (1993). "Wackernagel affixes: evidence from BaltoSlavic". In: Yearbook of Morphology 1992, 93-111.

Olander, Thomas (2009). Balto-Slavic Accentual Mobility. Berlin / New York: Mouton de Gruyter.

Parenti, Alessandro (1995a). "Dèl prūsų kalbos artikelio". In: Baltistica 30.2, 81-86.

Parenti, Alessandro (1995b). "Observations on the use of the definite adjective in Bretkūnas' translation of the New Testament". In: Res Balticae, 77-87.

Petit, Daniel (2007). "Case system and translation strategy in the Old Prussian Enchiridion". In: Baltistica 42.3, 347-382.

Petit, Daniel (2009). "La préhistoire des adjectifs déterminés du baltique et du slave". In: Bulletin de la Société de Linguistique de Paris 104.2, 311-36o.

Petit, Daniel (2010). Untersuchungen zu den baltischen Sprachen. Leiden / Boston: Brill. Petrauskas, Jonas and Aloyzas Vidugiris (1985). Lazūnų tarmès žodynas. Vilnius: Mokslas. 
Pokrotniece, Kornēlija (2002). Latviešu literārās valodas morfoloğiskās sistēmas attīstība. Latvijas Universitātes Latviešu valodas institūts.

Rinkevičius, Vytautas (2015). Prūsistikos pagrindai. Vilnius: Vilniaus universitetas.

Rosinas, Albertas (1972). "Žymimasis artikelis lietuivų kalbos tarmėse”. In: Kalbotyra XXIV.1, 83-9o.

Schulze, Wolfgang (2015). "From Caucasian Albanian to Udi". In: Iran and the Caucasus 19, 149-177.

Semėnienè, Loreta (2005). "Intranzityvinio subjekto žymejjimas vardininku ir / arba kilmininku". In: Acta Linguistica Lithuanica 52, 67-83.

Senn, Alfred (1966). Handbuch der litauischen Sprache. Heidelberg: Winter.

Seržant, Ilja (2014). "Denotational properties of the independent partitive genitive in Lithuanian". In: Grammatical Relations and their Non-Canonical Encoding in Baltic. Ed. by Axel Holvoet and Nicole Nau. Amsterdam / Philadelphia: John Benjamins, 257-299.

Specht, Franz (1929). Šyrwids Punktay sakimu (Punkty kazań). Göttingen:Vandenhoeck \& Ruprecht.

Spencer, Andrew and Ana R. Luís (2012). Clitics. An Introduction. Cambridge: Cambridge University Press.

Spraunienė, Birutė (2008a). "Apibrèžtumo kategorija ir jos tyrimai lietuvių kalbotyroje”. In: Lietuviu kalba 2.

Spraunienè, Birutė (2008b). "Paprastujjų ir ịvardžiuotinių būdvardžių opozicija lietuvių kalboje kaip apibrèžtumo sistema”. In: Acta Linguistica Lithuanica 59, 103-139.

Stang, Christian (1966). Vergleichende Grammatik der baltischen Sprachen. Oslo / Bergen / Tromsö: Universitetsforlaget.

Stolz, Thomas (2007). "Word-internal agreement". In: Sprachtypologie und Universalienforschung 60.3, 219-251.

Stolz, Thomas (2010). "Pleonastic morphology dies hard: Change and variation of definiteness inflection in Lithuanian". In: Variation and Change in Morphology. Ed. by Franz Rainer et al. Amsterdam / Philadelphia: John Benjamins, 217-244.

Trautmann, Reinhold (1910). Die altpreussischen Sprachdenkmäler: Einleitung, Texte, Grammatik, Wörterbuch. Göttingen: Vandenhoeck und Ruprecht.

Valeckienè, Adelè (1957). "Dabartinès lietuvių kalbos įvardžiuotinių būdvardžių vartojimas". In: Literatūra ir kalba 2, 161-328.

Velupillai, Viveka (2012). An Introduction to Linguistic Typology. Amsterdam / Philadelphia: John Benjamins.

Vidugiris, Aloyzas (2014). Lazūnų šnekta. Vilnius: Lietuvių kalbos institutas.

Zinkevičius, Zigmas (1957). Lietuviu kalbos įvardžiuotiniu būdvardžiu istorijos bruožai. Vilnius: Valstybinè politinès ir mokslinès literatūros leidykla.

Zinkevičius, Zigmas (1958). "Некоторые вопросы образования местоименных прилагательных в литовском языке”. In: Вопросы славянского языкознания 3, 50100. 
Zinkevičius, Zigmas (1978). "Dèl įvardžiuotinių būdvardžių raidos”. In: Lietuvių kalbotyros klausimai 18, 99-105.

Zwicky, Arnold M. and Geoffrey K. Pullum (1983). "Cliticization vs. inflection: English n't'. In: Language 59, 502-513. 